\title{
The transmission of socially responsible behaviour through international trade
}

Newman, Carol; Rand, John; Tarp, Finn; Trifkovic, Neda

Published in:

European Economic Review

DOI:

10.1016/j.euroecorev.2017.10.013

Publication date:

2018

Document version

Publisher's PDF, also known as Version of record

Document license:

CC BY-NC-ND

Citation for published version $(A P A)$ :

Newman, C., Rand, J., Tarp, F., \& Trifkovic, N. (2018). The transmission of socially responsible behaviour through international trade. European Economic Review, 101, 250-267.

https://doi.org/10.1016/j.euroecorev.2017.10.013 


\title{
The transmission of socially responsible behaviour through international trade
}

\author{
Carol Newman ${ }^{\mathrm{a}, *}$, John Rand ${ }^{\mathrm{b}}$, Finn Tarp ${ }^{\mathrm{b}, \mathrm{c}}$, Neda Trifkovic ${ }^{\mathrm{c}}$ \\ a Department of Economics and Trinity Impact Evaluation Unit, Trinity College, College Green, Dublin, Ireland \\ ${ }^{\mathrm{b}}$ Department of Economics, University of Copenhagen, Øster Farimagsgade 5, DK-1353 Copenhagen K, Denmark \\ ${ }^{\text {c } U N U-W I D E R, ~ K a t a j a n o k a n l a i t u r i ~} 6$ B, FI-00160 Helsinki, Finland
}

\section{A R T I C L E I N F O}

\section{Article history:}

Received 25 October 2016

Accepted 20 October 2017

Available online 6 November 2017

\section{JEL classification:}

D22

012

M14

\section{Keywords:}

Corporate social responsibility

Trade

Spill overs

Vietnam

\begin{abstract}
A B S T R A C T
We investigate the relationship between corporate social responsibility (CSR) practices of domestic Vietnamese firms and their engagement with foreign markets. We develop a measure of CSR that combines compliance with labour standards, management commitment to CSR, and corporate community related actions; and find a strong relationship between this measure and participation in international markets. Results suggest that both exporting and importing firms engage in more CSR activities. Conditional on exporting, we show that Vietnamese exporters to China are less involved in CSR related activities, and that exporters to the US engage in more community related CSR. This may reflect differences in stakeholder preferences across markets.
\end{abstract}

(c) 2017 The Author(s). Published by Elsevier B.V. This is an open access article under the CC BY-NC-ND license. (http://creativecommons.org/licenses/by-nc-nd/4.0/)

\section{Introduction}

The interest in corporate social responsibility (CSR) has grown rapidly in recent years in response to globalisation, limitations in government regulations and an increasing focus in civil society and the media on the ethical, social, and environmental aspects of business operations (Bénabou and Tirole, 2010). Firms have recognised that their conduct in purchasing and supply-chain management may have significant reputational and performance effects (Castka and Balzarova, 2008). To be sure, CSR can be used to enhance the image of firms and to attract consumers willing to pay for ethical attributes (Besley and Ghatak, 2007); and more responsible corporate behaviour reduces business risks including the threat of activist and consumer boycotts (Vogel, 2005). Apart from such outside considerations, CSR activities can be driven by internal motives; that is, manager or shareholder preferences for advancing broader social interests (Bénabou and Tirole, 2010).

In this study, we address externally driven motivations for CSR emerging from interactions between domestic firms and foreign stakeholders, such as consumers, foreign buyers of intermediate inputs and intermediate input suppliers. Our aim is to explore empirically the direct impact of trade on CSR practices of domestic firms in Vietnam. Domestic firms may observe and copy corporate social behaviour of export firms in export-intensive sectors in anticipation of entering export markets in the future. In addition, they may respond to increased competition from imports by imitating the standards of production

\footnotetext{
* Corresponding author.

E-mail addresses: cnewman@tcd.ie (C. Newman), john.rand@ku.dk (J. Rand), Finn@wider.unu.edu (F. Tarp), neda.trifkovic@econ.ku.dk (N. Trifkovic).
} 
of the imported goods, on the one hand, or by pursuing cost-reducing investments in CSR, on the other hand. As firms enter foreign markets (or start importing), they encounter preferences of new stakeholders, including foreign customers, both final consumers and buyers of intermediate inputs (or suppliers) and governments, which can affect their CSR activities. As CSR activities depend on the intensiveness of stakeholder pressures (Perez-Batres et al., 2010), the effect of trade on CSR may operate as well through the intensive margin - arising only after a threshold level of involvement with foreign stakeholders has been achieved.

CSR is defined here as a mix of legally compliant and philanthropic activities and we separate them to be in accordance with the different definitions of CSR commonly used. We measure CSR practices through (i) the extent to which the firm complies with labour standards, (ii) the management commitment to acting beyond the regulatory scope as reflected in the CSR strategy, and (iii) the engagement in community-based activities not directly linked to firm operations. These indicators are used to generate a CSR index that captures the overall level of CSR activities a firm engages in.

To determine the extent to which trade directly affects CSR, we examine whether firms that begin to trade in international markets change the nature and extent of their corporate social behaviour. We also consider the effect of trade at the intensive margin and examine the extent to which the effects are different for exports to and imports from different countries. One expects heterogeneity in the effect of trade on CSR, corresponding to the destination of exports or source country of imports if there is, for example, variability in stakeholder preferences across countries. Indirect effects are captured by analysing the extent to which the intensity of imports and exports into a sector affect the CSR activities of firms.

Our paper adds to the literature (reviewed in Section 2) by examining whether the transmission of CSR practices is an additional potential source of gain from global engagement. Furthermore, we contribute to the literature on the adoption of CSR, ${ }^{1}$ which has, to our knowledge, not to date considered explicitly the transfer of CSR practices from foreign markets to domestic firms.

CSR was introduced to Vietnam through codes of conduct requested by customers in foreign markets or multi-national companies (Nguyen, 2007). The Global Compact Network Vietnam was launched in 2007 in a joint effort between the United Nations, the Vietnam Chamber of Commerce and Industry, the Spanish Agency for International Cooperation, and Unilever Vietnam, motivating Vietnamese companies to pursue a set of core values in the areas of human rights, labour standards, the environment, and anti-corruption (UN, 2014). Furthermore, the United Nations Industrial Development Organization (UNIDO) is engaged in enhancing the sustainable integration of Vietnamese small and medium enterprises into global supply chains through increased awareness, understanding, and adoption of CSR (UNIDO, 2011). ${ }^{2}$ These initiatives followed wide-ranging reforms to enterprise, commercial and investment laws during the last decade. They have helped open the Vietnamese economy and give increased access to foreign markets for domestic firms. The reforms culminated in accession to the World Trade Organization (WTO) in 2007, contributing to the changing landscape for industrial development and increased trading opportunities.

Our key result is that exporting output and importing inputs has a positive impact on CSR activities, especially in terms of adherence to labour standards. Export firms are also more likely to increase management efforts and contributions to local communities in areas that are beyond the regulatory and business interests of the firm. Another result is that conditional on exporting, firms that export to China engage in significantly less CSR activities than firms exporting to other destinations. Finally, we do not find indirect CSR spill overs from trade.

The rest of this paper is structured as follows: Section 2 provides literature review and framing, while Section 3 presents the data, defines the measures of CSR practices used, and describes the measures of trade through which we propose the CSR transmission takes place. Section 4 outlines the empirical approach. Section 5 offers results, and Section 6 concludes.

\section{Literature review}

Exporting output or importing inputs can potentially enhance the productive capacity of domestic firms. Engaging in export markets has been associated with learning and efficiency gains (Van Biesebroeck, 2005; De Loecker, 2007; Blalock and Gertler, 2008; Lileeva and Trefler, 2010; Cruz et al., 2017; Newman et al., 2017), research and development (Aw et al., 2007, 2011), and innovation (Puga and Trefler, 2010). Similarly, importing inputs has been linked with productivity gains (Amiti and Konings, 2007; Fernandes, 2007; Kasahara and Rodrigue, 2008; Newman et al., 2016a). The main mechanism proposed so far in the literature to explain the association between productivity and engagement with global markets is that technology and learning are transmitted through the supply chain. In this paper, we propose that engaging with international customers, be they firms or final goods consumers, and with international suppliers, may encourage the transfer of other types of behaviour to domestic producers in the form of CSR.

\footnotetext{
${ }^{1}$ See the following studies focused on social, legal, or institutional pressures and expectations that motivate firms to adopt socially responsible practices (Baron, 2001; Delmas and Toffel, 2004; Matten and Moon, 2008; Gond et al., 2011) and several which consider corporate strategic interests in implementing CSR initiatives (Carroll, 1979; McWilliams and Siegel, 2001; Orlitzky et al., 2011).

2 In addition, the Fair Labour Association focuses especially on the apparel and footwear sector in a project that aims to improve work conditions and social compliance programmes in 50 garment factories (FLA, 2012).
} 
In its broadest sense, CSR refers to the creation of public 'goods' or the curtailment of public 'bads' by firms (Besley and Ghatak, 2007). According to ISO 26000 (ISO, 2012), a guideline on social responsibility of organisations, CSR is defined as the:

‘...responsibility of an organisation for the impacts of its decisions and activities on society and the environment, through transparent and ethical behaviour that contributes to sustainable development, including health and welfare of society; takes into account expectations of stakeholders; is in compliance with applicable law and consistent with international norms of behaviour; and is integrated throughout and practiced in an organisation's relationships.'

The definition proposed by ISO 26000 resonates with Schwartz and Carroll (2003), who identify CSR as a mix of economic, legal, and ethical responsibilities of businesses. ${ }^{3}$ The UN Global Compact also considers compliance with laws and regulations including, for example, labour conditions and anti-corrupt behaviour an integral part of CSR (UN, 2013). ${ }^{4}$ Newer definitions assume the economic component is given, referring to CSR as what firms do to further the social good beyond the immediate financial interests of the firm (McWilliams and Siegel, 2001). To illustrate, paying for health or education services in the local community furthers the social good and may not be in the immediate interest of the firm. Other types of CSR activity may benefit both society and the firm. Adherence to environmental standards is good for society and may also be good for business.

Firms can be motivated to engage in CSR practices to improve profits and for altruistic reasons (Kitzmueller and Shimshack, 2012). Porter and van der Linde (1995) highlight that economic performance can improve with the adoption of environment-friendly measures. Further studies have shown that CSR can increase firm profits by decreasing costs (Husted and de Jesus Salazar, 2006), differentiating products, and charging a price premium (Baron, 2001; McWilliams and Siegel, 2001), or by introducing technological and managerial innovations (Kanter, 1999). It is also possible that firm owners, managers, or shareholders proactively initiate CSR activities based on their personal preferences and interests, sacrificing profits to fulfil a broader social interest (Reinhardt et al., 2008). In other words, there may be an altruistic (not-for-profit) motivation to engage in CSR activities (Husted and de Jesus Salazar, 2006).

According to Kitzmueller and Shimshack (2012), the intersection of external and internal preferences reveals whether the CSR activities are strategic or altruistic. They propose that strategic CSR arises as a combination of internal profit-maximising and external social preferences. When both external and internal preferences are social in nature, the resulting type of CSR is altruistic. ${ }^{5}$ We propose that international trade is an important external driver of CSR activities, emerging through interactions between firms and stakeholders, which include consumers, suppliers, regulators, and activists. ${ }^{6}$ Demand-side pressures for CSR come from consumers, who derive higher utility by purchasing from firms with advanced social considerations (Kitzmueller and Shimshack, 2012).

Similarly, supplier pressure has been found to be important for the adoption of environmental certification for firms with a skilled work force (Albornoz et al., 2014). Regulators may sanction firms whose production has negative environmental or social externalities, so firms tend to adopt CSR to avoid paying fines. Furthermore, firms can undertake specific CSR actions to protect themselves from potential negative publicity associated with social activism (Baron, 2001). Corbett and Kirsch (2001) assert that countries with strong environment-friendly attitudes create social pressure for managers to adopt environmental standards.

Globalisation, increased international integration, and trade have expanded the range of stakeholders to whom firms are responsible. When a firm enters export markets, its stakeholders change from domestic customers and government to include foreign customers and destination country governments. ${ }^{7}$ Similarly, if a firm begins importing inputs, the range of stakeholders expands to foreign suppliers and source-country governments. Firms that are part of an integrated supply chain may have no choice but to adhere to higher standards of production.

Accordingly, increased engagement in global markets is likely to affect the CSR practices of firms through these mechanisms if firms care about the preferences of their stakeholders in terms of CSR, and assuming the preferences of foreign

\footnotetext{
${ }^{3}$ This three-domain approach is derived from Carroll's four domains of corporate social responsibility, see (Carroll, 1979) and the Pyramid of CSR (Carroll, 1991).

${ }^{4}$ Note that in some definitions, CSR refers to firm activities that go beyond the law in integrating social, environmental, ethical, and consumer concerns into their business operations to create shared value for shareholders and stakeholders (McWilliams and Siegel, 2001; Bénabou and Tirole, 2010; Crifo and Forget, 2015). Societal expectations are that firms realise their economic objectives within the legal framework (Carroll, 1979). While this is often taken as given in advanced economies, it may not be the case in developing countries. A case in point includes situations where the rule of law is not enforced to the extent expected from foreign stakeholders (see, e.g. Barrett et al., 2002).

${ }^{5}$ We do not have direct information (e.g. from managers) on the main internal motives for engaging in specific CSR activities. Without this information, we are unable to classify the types of CSR activities observed along the for- or not-for-profit dimensions, and testing for how particular CSR activities affect profit is beyond the scope of this paper. We investigate if the types of CSR activities observed (compliance, management and community) arise due to external factors, such as international trade.

${ }^{6}$ Investors may also motivate specific types of CSR activities, depending on their preferences (Kolstad, 2016). Furthermore, Aldashev et al. (2015) show in a theoretical model that the pressure from non-governmental organisations for firms to act in socially responsible manner can trigger changes in the industry structure.

7 Potoski and Prakash (2004) argue that if key export destinations adopt ISO 14000, pressures through trade linkages create incentives for ISO 14000 adoption. Herzfeld et al. (2011) find that firms from developing countries, which trade with advanced European countries, are more likely to certify private standards, emphasizing destination country stakeholder preferences.
} 
stakeholders are different to those of domestic customers, suppliers, and government. ${ }^{8}$ The intensity of relations with foreign stakeholders may also play a role, implying that the adoption of CSR practices does not occur until a sufficiently high level of involvement with foreign stakeholders is achieved. ${ }^{9}$

Finally, CSR can arise as a spill over from trade. For example, domestic firms may observe and copy the CSR practices of export firms in export-intensive sectors in the hope of entering export markets in the future. Equally, they may respond to increased competition from imports by mimicking the standards applied to those goods to compete, or may be forced to reduce investments in CSR as a reaction to increased competition. ${ }^{10}$

\section{Data}

The data on which we rely come from several sources. The CSR information are from four rounds of the Vietnam Technology and Competitiveness Survey (TCS) through which we gathered detailed information on the CSR practices of a sample of more than 4500 private domestic Vietnamese manufacturing enterprises annually between 2010 and 2013 (CIEM, 2012 , 2013, 2014, 2015). The TCS covered a representative sample of manufacturing firms contained in the larger Vietnam Enterprise Surveys (VES), administered annually by the General Statistical Office (GSO), and involving more than 50,000 manufacturing firms (GSOV, 2016b). While we focus the core part of our analysis on the balanced panel of 2546 firms, we also present results for the unbalanced panel.

Information on CSR is gathered along three main dimensions: labour conditions, management commitment, and community involvement. We also use the TCS survey instrument as source on the extent of engagement of firms with foreign markets; while the VES provides balance sheet and other information on the activities of firms. The TCS Survey was administered at the same time and under the same circumstances as the VES, which is mailed out to firms, which submit the completed questionnaires by return post to the Provincial Statistics Office. Under the Law on Statistics, all firms are legally required to comply. Any firms that do not respond are contacted by provincial authorities by mail, by phone, or through face-to-face visits. All data gathered are checked by the GSO for internal consistency and crosschecked with the administrative provincial data before being made available.

We matched the TCS data for the sampled firms with information on the activities of firms and their financial accounts gathered using the main VES instrument, which produced a rich database which we make use of here. Finally, the values of sector-level (4-digit) imports and exports are taken from the UN COMTRADE database available through World Integrated Trade Solutions.

\subsection{CSR measures}

Following the Schwartz and Carroll (2003) CSR approach, the UN Global Compact (2013) and ISO 26000 guidance for CSR (ISO, 2012), we address several dimensions of socially responsible firm activities that can be internal to the firm or external in the form of contributions to the local community. In constructing the CSR indicators, we cover, as noted, compliance CSR, management-related CSR, and community-related CSR practices gathered in our specially designed survey instrument. ${ }^{11}$

Table 1 provides a description of each CSR indicator. The compliance CSR category follows the Schwartz and Carroll (2003) legal domain of corporate responsibilities, which are defined as firm responsiveness to society's legal expectations mandated through legal principles and jurisdictions. We focus on national labour regulation ${ }^{12}$ measured using four indicators that show whether: (i) all permanent employees have a written labour contract; (ii) the firm has a local trade union; (iii) the firm pays social insurance; and (iv) the firm pays health insurance to employees. CSR management provisions measure the extent of management effort in going beyond regulatory compliance when assuring socially and environmentally sound practices. This is a crucial component of CSR as interests of managers and directors may drive CSR (Jensen, 2002).

We measure CSR management requirements by observing whether a firm has: (i) a committee that oversees CSR practices; (ii) a written CSR policy; (iii) received CSR-type certificates; and (iv) whether the firm is a member of any groups that

\footnotetext{
8 These mechanisms are supported by Gereffi et al. (2005). They propose that in supply chains where buyers are concentrated (for example, retailers or brand-name companies) and suppliers remain fragmented (the so-called buyer-driven chains), requirements about products and production processes are passed backwards from buyers to suppliers. Similarly, in industries where the manufacturers are the most powerful actors in the supply chain (the socalled producer-driven chains, such as automotive industry, energy, and electronics), downstream firms are the recipients of specific product and conduct requirements.

9 Perez-Batres et al. (2010) find that the range of CSR activities depends on the intensiveness of the stakeholder pressures.

10 There is evidence to suggest that firms are more likely to adopt environmental practices when local competitors have done so (Zhu et al., 2012; Fikru, 2014).

11 There is no single best way of measuring CSR (Crifo and Forget, 2015). See Turker (2009) for an overview of some methods for measuring CSR, as well as BCCCC (2011) and Gjølberg (2009) for different approaches. Earlier literature questions how well CSR metrics reflect CSR behaviours and performance (Chatterji et al. 2009). We rely on self-reported measures of CSR activities and acknowledge that some of the CSR activities included in our CSR index may not have direct implications for firm operations. For example, a written-down CSR policy may not be implemented in practice. We have, however, indicators that are expected to affect firm operations. For example, obtaining a CSR-type certification is more objective as it implies changes in firm operations and requires verification by a third party that specific requirements have been fulfilled.

12 The dataset does not contain information on the compliance with domestic environmental or food safety and quality regulation, so the compliance CSR refers to labour standards only. Exporters are likely to comply with destination country regulations, which is usually demonstrated by obtaining certificates of compliance with international standards. Due to voluntary nature of such certifications, we include them in management, not compliance CSR.
} 
Table 1

Description of core variables.

\begin{tabular}{|c|c|}
\hline Variable name & Description \\
\hline \multicolumn{2}{|l|}{ CSR measures } \\
\hline CSR compliant & Extent to which firm complies voluntarily with domestic labour regulation ( 4 indicators) \\
\hline CSR management & $\begin{array}{l}\text { Extent to which firm has a well-developed CSR strategy at the management level that goes beyond } \\
\text { compliance with existing regulations ( } 4 \text { indicators) }\end{array}$ \\
\hline CSR community & $\begin{array}{l}\text { Extent to which firm engages in beyond compliance community-based activities not directly } \\
\text { related to firm operations ( } 8 \text { indicators) }\end{array}$ \\
\hline CSR index & Index based on all 16 indicators \\
\hline \multicolumn{2}{|c|}{ Firm-specific trade measures } \\
\hline Exports output & Dummy indicator for whether firm exports output \\
\hline Imports inputs & Dummy indicator for whether firm imports inputs \\
\hline Export proportion & Proportion of output exported \\
\hline Import proportion & Proportion of inputs imported \\
\hline \multicolumn{2}{|c|}{ Sector-specific trade measures } \\
\hline Exports into sector & Value of exports in total sales of the 4-digit sector \\
\hline Imports into sector & Value of imports in total sales of the 4-digit sector \\
\hline Exporter share & 4-digit sector share of exporting firms \\
\hline Importer share & 4-digit sector share of importing firms \\
\hline
\end{tabular}

promote CSR standards. ${ }^{13}$ CSR community provisions follow the Schwartz and Carroll (2003) ethical domain, which refers to both domestic and global ethical responsibilities of businesses as expected by the general population and relevant stakeholders. They measure the way in which firms contribute to the local community in areas that are beyond the business interests of the firm. We measure the CSR community component in terms of firm activities related to: (i) environment protection; (ii) education; (iii) infrastructure development; (iv) healthcare services; (v) youth programmes; (vi) poverty alleviation; (vii) local heritage protection; and (viii) sporting events.

For each category, we score firms by giving them a point for each of the CSR activities they practice. Combining the scores across all three measures produces our CSR index that shows the overall amount of CSR activities by the firm (on a scale of 0-16). The building components of the CSR index may not operate independently. Newman et al., (2016b) show that there can be a high degree of overlap between certain activities. For example, firms carrying out management-related CSR are more likely to engage in compliance CSR, while each of the community based CSR involvements are less linked to other types of CSR. ${ }^{14}$

\subsection{Measuring trade linkages}

Arguably, the transfer of CSR practices can occur directly through interactions with foreign markets, indirectly through spill overs from import competition, or by mimicking the behaviour of firms within the same sector. We measure direct connectedness to foreign markets with two dummy variables for whether a firm imports inputs or exports outputs. The export and import intensity are measured by the shares of export or import in firm revenue.

The sector variables used to capture spill overs are measures of within-sector foreign trade intensity. The extensive export and import margins are captured by the share of exporting and importing firms in each 4-digit sector, respectively. The intensive margins are measured, as the shares of the deflated value of exports and imports in sector total sales. For a brief description of the indicators of trade considered see Table 1.

\subsection{Descriptive statistics}

Table 2 presents a summary of the CSR practices of firms in the full TCS sample along with a summary of the trade linkage indicators. We present the means for all surveyed firms (i.e. all ownership types) for the subset of domestic private firms and for the subset of domestic private firms for which we have a balanced panel. The most prominent form of CSR activity is compliance with labour regulations. This has the highest score with just below three out of the four possible requirements fulfilled by firms on average. Private domestic firms have slightly lower scores than the full sample of firms on the CSR compliance indicator.

Management commitment to CSR shows that firms apply only slightly more than one out of the four possible activities from this category. Again, private domestic firms have lower than average scores for CSR management. Firm contributions

\footnotetext{
13 In the context of this study, management CSR should not be confounded with CSR arising from moral hazard. Kitzmueller and Shimshack (2012) explain that CSR can result from moral hazard when managers decide to invest in CSR at the expense of wealth creation. Analysing whether CSR activities affect firm performance is beyond the scope of this paper, so we interpret this CSR type as a dedication of firm leadership to CSR.

14 Short of strong theoretical guidance on how to weigh different components of the CSR index, we a conduct principal component analysis. Using the first principal component instead of the CSR index does not change the main results. The estimation results are available upon request.
} 
Table 2

Descriptive statistics: firm-specific measures.

\begin{tabular}{|c|c|c|c|c|c|c|c|c|c|c|c|c|}
\hline & \multicolumn{4}{|c|}{ All firms } & \multicolumn{4}{|c|}{ Private domestic firms } & \multicolumn{4}{|c|}{ Private domestic firms (balanced) } \\
\hline & 2010 & 2011 & 2012 & 2013 & 2010 & 2011 & 2012 & 2013 & 2010 & 2011 & 2012 & 2013 \\
\hline \multicolumn{13}{|l|}{ CSR measures (mean) } \\
\hline CSR compliant & 2.92 & 2.94 & 2.95 & 3.09 & 2.63 & 2.66 & 2.65 & 2.82 & 2.79 & 2.81 & 2.76 & 2.93 \\
\hline CSR management & 1.21 & 1.21 & 1.36 & 1.34 & 1.13 & 1.12 & 1.26 & 1.26 & 1.18 & 1.18 & 1.3 & 1.29 \\
\hline CSR community & 0.77 & 0.84 & 0.77 & 0.75 & 0.84 & 0.91 & 0.85 & 0.83 & 0.88 & 0.97 & 0.91 & 0.92 \\
\hline CSR index & 4.90 & 4.99 & 5.08 & 5.18 & 4.60 & 4.70 & 4.76 & 4.91 & 4.85 & 4.96 & 4.97 & 5.14 \\
\hline Observations & 6301 & 6463 & 5999 & 6073 & 4705 & 4798 & 4374 & 4465 & 2546 & 2546 & 2546 & 2546 \\
\hline \multicolumn{13}{|l|}{ Linkage variables (\%) } \\
\hline & 2009 & 2010 & 2011 & 2012 & 2009 & 2010 & 2011 & 2012 & 2009 & 2010 & 2011 & 2012 \\
\hline Exports output & 32.45 & 32.92 & 36.05 & 37.51 & 20.13 & 21.73 & 22.55 & 22.41 & 21.33 & 23.68 & 24.82 & 25.33 \\
\hline Imports inputs & 33.32 & 33.99 & 33.37 & 28.67 & 19.43 & 18.70 & 17.80 & 13.60 & 20.23 & 21.52 & 20.62 & 16.03 \\
\hline Export proportion & 11.64 & 24.30 & 23.80 & 24.18 & 7.10 & 14.46 & 14.25 & 13.62 & 7.58 & 15.78 & 15.53 & 15.26 \\
\hline Import proportion & 13.48 & 19.38 & 19.01 & 11.93 & 6.96 & 8.81 & 8.41 & 4.44 & 7.00 & 9.96 & 9.56 & 5.06 \\
\hline Exporter share & 4.31 & 14.07 & 16.16 & 14.78 & 3.98 & 12.77 & 14.28 & 12.89 & 4.03 & 12.75 & 14.36 & 13.07 \\
\hline Importer share & 14.23 & 14.28 & 21.22 & 18.66 & 12.81 & 12.51 & 19.39 & 16.79 & 12.9 & 12.69 & 19.36 & 16.87 \\
\hline Exports into sector & 5.86 & 5.44 & 4.07 & 4.63 & 5.66 & 5.42 & 3.71 & 4.51 & 4.81 & 6.62 & 3.74 & 5.31 \\
\hline Imports into sector & 14.06 & 12.00 & 6.21 & 6.67 & 16.88 & 13.98 & 6.84 & 7.69 & 11.69 & 20.17 & 8.46 & 9.25 \\
\hline Observations & 6009 & 6301 & 6463 & 5999 & 4432 & 4705 & 4798 & 4374 & 2546 & 2546 & 2546 & 2546 \\
\hline
\end{tabular}

Source: Authors' calculations based on data obtained from the Vietnam Technology and Competitiveness Survey (CIEM, 2012, 2013, 2014, 2015).

Note: Linkage variables enter the estimations in lags so we show 2009-2012 values.

to the community in which they operate are measured in eight dimensions. This is where we see the lowest level of engagement in CSR activities, dropping to below one on a possible range of zero to eight. Compared to the sample average, domestic private firms show a slightly higher level of community-related CSR activities.

The average CSR index scores for all surveyed firms is around five (out of 16) and is slightly lower for private domestic firms. With only every third firm engaged in one possible CSR practice, the overall adherence to CSR practices among firms in Vietnam is low. The level of CSR overall is, however, increasing. This is due to compliant and management rather than community CSR.

Table A.1 in the Appendix shows the incidence of all 16 types of CSR activities defined in Table 1. As expected, firms engage in compliance CSR more often than in voluntary CSR. Around three-quarters of firms provide social and health insurance and around $95 \%$ of firms have written labour contracts for all employees. The share of firms with a local trade union is just above 50\%. According to the Trade Union Law of 1994 enterprises with 10 or more workers are required to establish a local trade union. These local trade unions operate under the auspices of the Vietnam Confederation of Labour, overseen by the Communist Party of Vietnam. In terms of beyond compliance indicators, around two-thirds of firms have a CSR policy and around 10 per cent have some type of CSR certification, such as ISO 14001, OHSAS 18001 and SA8000. ${ }^{15}$

The most common community-based activities are environmental protection and poverty alleviation. One in four firms contribute to environmental protection and one in five to local poverty alleviation projects. Less than $10 \%$ of firms contribute to educational programmes, for example, in the form of scholarships and infrastructure development. Other community activities, such as youth support and local heritage protection are reported by less than five per cent of firms. Engagement in different CSR activities has been stable in the observed period. A notable change has been the increase in social and health insurance contributions and the committees that oversee CSR practices. Firms observed in all four time-periods show a lower prevalence of trade unions and social and health insurance contributions and a higher prevalence of environmental protection, education and poverty alleviation projects compared to unbalanced panel. Differences in other indicators are very small.

Examining the trade linkage variables that measure the engagement of Vietnamese firms with foreign markets, our data show that around one-third of firms are engaged in foreign trade either through the purchase of inputs or through the sale of outputs (Table 2). While private domestic firms are less engaged with foreign markets, the extent of export engagement is increasing. The sector share of importers is larger than the sector share of exporters. Likewise, the value of exports is smaller than the value of imports in the sector. ${ }^{16}$

Summary statistics for the sector-specific measures of linkages with foreign firms and markets are presented in Table $3 .{ }^{17}$ We observe a lot of variation in the trade intensity of sectors. In 2012, the most export intensive sector was sector 29 (motor vehicles), followed by sectors 16 (computer, electronic and optical products) and 21 (pharmaceuticals).

\footnotetext{
15 These standards are usually accompanied by quality and safety management standards, such as ISO 9001 and HACCP.

16 Summary statistics for the firm-specific control variables are provided in Table A of the online Appendix.

17 In the empirical analysis, imports and exports are aggregated at the 4-digit level. They are presented here at the 2-digit level for ease of exposition.
} 
Table 3

Descriptive statistics: sector-specific measures.

\begin{tabular}{|c|c|c|c|c|c|c|c|c|}
\hline \multirow[b]{2}{*}{ VSIC sector } & \multicolumn{4}{|c|}{ Proportion of exporters } & \multicolumn{4}{|c|}{ Proportion of importers } \\
\hline & 2009 & 2010 & 2011 & 2012 & 2009 & 2010 & 2011 & 2012 \\
\hline 10 Food & 3.53 & 14.74 & 13.10 & 13.24 & 10.72 & 10.04 & 22.32 & 20.36 \\
\hline 11 Beverages & 2.51 & 3.41 & 8.54 & 9.89 & 9.40 & 7.77 & 10.19 & 11.66 \\
\hline 13 Textiles & 5.49 & 18.99 & 21.97 & 19.29 & 18.49 & 18.98 & 26.28 & 24.03 \\
\hline 14 Apparel & 5.17 & 21.59 & 17.35 & 16.16 & 11.76 & 15.89 & 25.75 & 22.94 \\
\hline 15 Leather & 8.31 & 29.46 & 14.57 & 12.64 & 22.57 & 26.22 & 17.87 & 14.70 \\
\hline 16 Wood & 2.62 & 9.49 & 6.22 & 4.92 & 5.06 & 4.36 & 13.27 & 9.73 \\
\hline 17 Paper & 2.58 & 9.39 & 13.90 & 12.35 & 11.49 & 10.76 & 17.84 & 15.43 \\
\hline 18 Printing & 0.52 & 1.65 & 3.54 & 2.24 & 3.80 & 3.05 & 4.58 & 2.81 \\
\hline 20 Chemicals & 5.70 & 14.62 & 26.31 & 21.75 & 22.60 & 22.07 & 28.51 & 24.25 \\
\hline 21 Pharmaceuticals & 8.12 & 18.12 & 28.37 & 29.65 & 29.52 & 30.66 & 31.52 & 32.61 \\
\hline 22 Rubber & 5.50 & 17.34 & 24.39 & 21.98 & 21.49 & 22.09 & 29.10 & 25.02 \\
\hline 23 Non-metallic minerals & 3.34 & 7.69 & 9.07 & 7.89 & 10.12 & 7.70 & 13.20 & 11.06 \\
\hline 24 Basic metals & 3.47 & 9.18 & 21.21 & 19.20 & 15.02 & 16.05 & 23.72 & 21.71 \\
\hline 25 Fabricated metal & 2.12 & 7.66 & 11.07 & 10.49 & 10.36 & 10.09 & 13.16 & 11.63 \\
\hline 26 Electronics & 7.94 & 29.95 & 46.60 & 35.12 & 23.36 & 36.67 & 48.37 & 38.59 \\
\hline 27 Electrical equipment & 8.35 & 22.84 & 30.33 & 27.32 & 29.35 & 31.03 & 33.38 & 28.77 \\
\hline 28 Other machinery and equipment & 2.46 & 9.10 & 17.74 & 17.33 & 17.57 & 16.47 & 20.44 & 17.98 \\
\hline 29 Motor vehicles & 7.97 & 28.30 & 51.53 & 51.78 & 46.89 & 47.32 & 54.58 & 53.66 \\
\hline 30 Other transport equipment & 4.14 & 16.90 & 28.26 & 27.88 & 29.77 & 25.24 & 30.96 & 30.20 \\
\hline 31 Furniture & 8.28 & 18.95 & 14.98 & 12.51 & 14.74 & 14.07 & 21.50 & 18.28 \\
\hline 32 Other manufacturing & 4.68 & 21.59 & 25.28 & 23.01 & 15.74 & 20.61 & 31.41 & 26.09 \\
\hline Total & 3.53 & 14.74 & 13.10 & 13.24 & 10.72 & 10.04 & 22.32 & 20.36 \\
\hline
\end{tabular}

Source: Authors' calculations based on the Vietnam Technology and Competitiveness Survey (CIEM, 2012, 2013, 2014, 2015).

Note: VSIC stands for Vietnam Standard Industry Classification, which follows the structure of International Standard Industrial Classification of All Economic Activities, Rev. 4. Sector 12 (Manufacture of tobacco products) and sector 19 (Manufacture of coke and refined petroleum products) are excluded due to very few firms present in these sectors. Descriptive statistics for 2009 are included in the table as lags of these variables are used in the regression analysis.

These sectors were also the most import intensive. For most sectors, the proportion of firms that export/import has been growing. This reflects the increased extent of global engagement of Vietnamese firms with world markets.

Table A.2 in the Appendix shows average values of CSR indicators among exporting and importing firms for the full sample, the subsample of domestic private firms and the balanced panel. Firms that do not trade internationally had lower average scores for all types of CSR activities than exporters and importers throughout the observed period. The average CSR index score is higher for importers, but the value of the index has grown more for the exporters in the observed period. Importers have emphasised CSR compliant and management activities, while exporters have focused on community CSR. Similarly, we find that the CSR index increases with the proportion of inputs that are imported by firms but that a higher share of final goods that are exported does not guarantee more CSR (results not shown).

\section{Empirical approach}

The impact of trade on CSR practices is investigated through the estimation of Eq. (1):

$$
\operatorname{CSR}_{i j t}=\alpha_{i}+\boldsymbol{\beta}_{1} \mathbf{F}_{i j t-1}+\boldsymbol{\beta}_{2} \mathbf{S}_{j t-1}+\boldsymbol{\beta}_{3} \mathbf{X}_{i j t}+\theta_{j}+\tau_{t}+e_{i j t}
$$

where $i$ denotes firm, $j$ sector and $t$ the time-period. $\alpha_{i}, \theta_{i}$, and $\tau_{i}$ are, respectively, firm, sector, and time fixed effects. $e_{i j t}$ is the statistical noise term. The dependent variable, $\operatorname{CSR}_{i j t}$ is the firm-level measure of engagement in CSR practices. We consider four different CSR indicators: the overall CSR index, the compliant CSR index, the management CSR index, and the community CSR index, constructed as described in Table 1.

Eq. (1) explains CSR behaviour as a function of firm- and sector-level exposure to foreign markets. The firm-specific trade linkage variables are grouped in the vector $\mathbf{F}_{i j t-1}$, while sector measures are captured in the vector $\mathbf{S}_{i j t-1}$. Both are included at a lag. ${ }^{18}$ The vector $\mathbf{X}_{i j t}$ comprises time-varying firm- and sector-specific control variables identified previously as systematic determinants of the propensity to engage in CSR. We control for profitability by including the profit to assets ratio and include the log value of value added, labour, and capital to capture differences between firms in size, visibility, and the choice of technology. ${ }^{19}$ These factors are likely to impact on the extent of engagement of firms with CSR activities and participation in foreign markets making them important control variables. Campbell (2007) asserts that less profitable firms are less likely to engage in socially responsible practices as they have fewer resources to spare for such activities.

We include the number of employees as our measure of enterprise size. Firm size has been found to affect positively the decision of firms to engage in CSR practices (McWilliams and Siegel, 2001). Moreover, larger firms may find it easier

\footnotetext{
18 We also have data for the sector- and firm-specific variables for previous rounds using the lagged variables, which do not involve any loss of observations.

${ }^{19}$ We use the total assets of the firm as the measure of capital. All results are robust to the inclusion of fixed assets as the capital control variable.
} 
to finance CSR-related activities, for example, to make the necessary adjustments in the production process to comply with environmental regulation or investments in community projects. Value added is computed using data on profits and wages deflated using an annual GDP deflator. The profit to assets ratio is the deflated value of gross profits relative to the deflated value of assets. Some types of production may call for more engagement in CSR practices (McWilliams and Siegel, 2001). For example, some firms may find it more relevant for their specific type of production to certify internationally recognised environmental standards such as ISO 14001 to demonstrate responsible environmental management. We control for the technology in use by the value of capital. This is measured as the deflated value of the total assets of the firm at the end of the year.

We expect that larger, more efficient, technologically advanced firms will be more likely to engage in more CSR activities as measured by the CSR index, starting from compliance and management to community CSR. As is clear from Table A.1 in the Appendix, firms tend to concentrate their CSR around the compliance activities. There is no reason to believe that firm characteristics would have an impact on this component of CSR if the rule of law applies equally to everyone. The advantages of firm size and efficiency would start to be observable in terms of management and community CSR activities, as larger and more efficient firms would have more human capital and financial resources to devote to such activities. For example, human resource constraints may be relevant for management CSR in small firms as they may not have sufficiently qualified personnel to develop a CSR policy. Less efficient firms may not be able to achieve a financial surplus which they can donate to community projects such as infrastructure development.

We also include a control variable that captures the level of concentration in a specific sector. The measure used for this purpose is the Herfindahl-Hirschman Index (HHI), defined as the sum of the squared market shares within a sector. Higher values of the index imply weaker competition and thus greater concentration in a specific sector. The market shares are computed using the full dataset available from the VES based on the revenue data reported by each individual firm. Competition can either increase or decrease CSR behaviour. Competitive sectors have higher rates of CSR adoption, but when competition is extremely fierce, firms may act in socially irresponsible ways to save money due to already meagre profit margins (Shleifer, 2004; Campbell, 2007). Likewise, when competition is low, firms may lack incentives to engage in socially responsible behaviour as a source of competitive advantage (Porter and Kramer, 2002; Campbell, 2007). ${ }^{20}$

Identifying a causal relationship between trade linkages and CSR activity is challenging for several reasons. There may be unobserved firm-specific characteristics influencing the CSR policy that are also correlated with the extent to which firms are linked with foreign firms or international markets. For example, a manager of a firm may have international experience, which could lead to more CSR and more foreign trade. Moreover, a firm's position in the supply chain may make it more likely to engage in both foreign trade and undertake more (or less) CSR activities. Firm-fixed effects address this issue to some extent given that they allow us to control directly for all time-invariant unobserved firm-specific factors, such as manager characteristics and position in the supply chain. Sector-fixed effects control for sector switchers, of which there are many in Vietnam (around 7\% of our sample), while time dummies control for general trends affecting all firms and sectors. $^{21}$

It is possible, even with this rich combination of fixed effects and time-varying control variables, that other sources of bias remain. For example, there may be omitted time-varying unobservable firm- and sector-specific factors that impact on both the decision to trade internationally and CSR activities such as a change in management. Similarly, our model will not control for time-varying sector specific shocks that impact on both sector-level trade and CSR such as a new sector-specific regulation on environmental or labour standards. Consequently, standard OLS fixed effects estimates will be biased. It is not clear, however, what the direction of the bias will be. A change in management could lead a firm both to trade more and to engage in more CSR in which case OLS estimates will have a positive bias. It may also be that new management reduces the extent of CSR activities to direct investment into preparing products for export markets or purchasing imported inputs. Similarly, a sector-specific change in regulations on CSR may force firms to engage in more CSR and divert investment away from production-related activities important for participation in export markets. It may also lead firms to switch to imported inputs to avoid having to comply with regulations. A second source of potential bias is simultaneity, which could arise if exporting and importing are more likely to be associated with firms and sectors where firms are already socially responsible. This means that the direction of causality may be difficult to disentangle.

To correct for these potential sources of omitted variable bias we rely on a two-step difference GMM estimator (Arellano and Bond, 1991). A first difference transformation is used to eliminate the firm-specific fixed effect (as opposed to the fixed effects estimator) allowing earlier lags of the endogenous variables to be used as instruments. This implies that (assuming no second order autocorrelation) the second lag (and earlier) of each of the firm and sector-specific variables are available as instruments. We also use GMM-style instruments for the other firm-specific control variables for which the first lag and

\footnotetext{
20 Newman et al. (2016b) find for Vietnamese manufacturing firms that CSR adoption is efficiency enhancing for firms, and even more so in uncompetitive sectors, suggesting that differentiating products through CSR may indeed be difficult in highly competitive sectors while at the same time there may be incentives to engage in CSR in concentrated sectors.

21 Firms switching sectors is a very common occurrence in the Vietnamese manufacturing sector and is indicative of the dynamic nature of the private sector. Newman et al. (2013) examine this phenomenon in detail. As such, even though the model includes firm-fixed effects, which will absorb all time invariant sector-specific effects for non-switchers, we also include sector-fixed effects to control for differences in sector-specific factors for firms that switch from one sector to another.
} 
Table 4

Variation in core variables over the $2010-13$ period (balanced panel).

\begin{tabular}{|c|c|c|c|c|c|c|c|c|c|}
\hline \multirow[b]{2}{*}{ Variable name } & \multicolumn{3}{|l|}{ 2010-11 } & \multicolumn{3}{|l|}{$2011-12$} & \multicolumn{3}{|l|}{$2012-13$} \\
\hline & $\begin{array}{l}\text { Average } \\
\text { change }\end{array}$ & $\begin{array}{l}\text { Percent } \\
\text { increase }\end{array}$ & $\begin{array}{l}\text { Percent } \\
\text { decrease }\end{array}$ & $\begin{array}{l}\text { Average } \\
\text { change }\end{array}$ & $\begin{array}{l}\text { Percent } \\
\text { increase }\end{array}$ & $\begin{array}{l}\text { Percent } \\
\text { decrease }\end{array}$ & $\begin{array}{l}\text { Average } \\
\text { change }\end{array}$ & $\begin{array}{l}\text { Percent } \\
\text { increase }\end{array}$ & $\begin{array}{l}\text { Percent } \\
\text { decrease }\end{array}$ \\
\hline \multicolumn{10}{|l|}{ CSR measures } \\
\hline CSR compliant & 0.024 & 4.78 & 4.65 & -0.047 & 3.90 & 4.20 & 0.163 & 4.54 & 1.19 \\
\hline CSR management & -0.001 & 7.75 & 7.88 & 0.120 & 6.81 & 3.78 & -0.004 & 4.74 & 5.11 \\
\hline CSR community & 0.085 & 7.11 & 5.79 & -0.059 & 4.98 & 5.80 & 0.006 & 4.53 & 4.62 \\
\hline \multirow[t]{2}{*}{ CSR index } & 0.107 & 11.10 & 10.33 & 0.014 & 9.87 & 9.11 & 0.165 & 9.48 & 7.44 \\
\hline & \multicolumn{2}{|c|}{ 2009-2010 } & \multicolumn{2}{|c|}{ 2010-2011 } & \multicolumn{2}{|c|}{ 2011-2012 } & \multicolumn{2}{|c|}{ 2012-2013 } & \\
\hline Linkage variables & $\begin{array}{l}\text { Percent } \\
\text { start }\end{array}$ & $\begin{array}{l}\text { Percent } \\
\text { stop }\end{array}$ & $\begin{array}{l}\text { Percent } \\
\text { start }\end{array}$ & $\begin{array}{l}\text { Percent } \\
\text { stop }\end{array}$ & $\begin{array}{l}\text { Percent } \\
\text { start }\end{array}$ & $\begin{array}{l}\text { Percent } \\
\text { stop }\end{array}$ & $\begin{array}{l}\text { Percent } \\
\text { start }\end{array}$ & $\begin{array}{l}\text { Percent } \\
\text { stop }\end{array}$ & \\
\hline Exports output & 8.4 & 6.0 & 5.9 & 4.8 & 3.2 & 2.7 & 2.5 & 2.5 & \\
\hline Imports inputs & 7.8 & 6.5 & 3.6 & 4.5 & 2.9 & 7.5 & 2.9 & 3.1 & \\
\hline
\end{tabular}

Source: Authors' calculations based on data obtained from the Vietnam Technology and Competitiveness Survey (CIEM, 2012, 2013, 2014, 2015). Note: Number of firms: 2546.

earlier are valid instruments. We provide more details on the exact lag structure and the validity of the instrument sets in the results section.

Using this approach, the parameters are identified using the within-firm variation in CSR and engagement with foreign firms over time. Given the short time-series of our panel (2010-13) this limits the extent of variation that is used to identify the parameters and may run the risk of weakly identified coefficients. Moreover, the first-difference specification requires that firms are present for at least two consecutive time periods. To avoid the possibility that parameter estimates are influenced by the exit and entry of firms rather than within-firm variations, we use a balanced panel of firms that are present in every year for our main analysis and conduct robustness checks using the unbalanced panel. The extent of the within-firm variation in the main variables of interest in the balanced panel is presented in Table 4.

There is a lot of within-firm variation in the CSR indicators between years. Around $10 \%$ of firms either increase or decrease their score annually. The variation in the import and export status of firms is much lower. On average around $5 \%$ of firms enter or exit from export/import markets each year. We therefore expect the standard errors on these variables to be large implying that any statistical significance observed is a lower bound.

\section{Results}

Table 5 presents results of our analysis of the impact of trade on CSR. In panel A, the dependent variable is the aggregate CSR index. We estimate Eq. (1) using OLS, a firm-fixed effects estimator, and the difference GMM estimator. All models include time dummies. Sector-fixed effects and the control for industry concentration are included in the last column. In column (1), we present the OLS estimates of the model, which links the indicators for whether a firm exports or imports with CSR. We estimate this using the full sample available. In column (2), we restrict the sample to that which is available for estimation using the more demanding difference GMM specification for comparison purposes.

Reassuringly, the coefficients in columns (1) and (2) are quite similar suggesting a positive correlation between the export of output and the level of CSR activity of the firm. The coefficient on the indicator for importing imports is not statistically significant. In column (3), we move to a fixed effects estimator, which controls for all firm-specific time-invariant heterogeneity. Unsurprisingly, the magnitude of the coefficient on the export indicator declines slightly. The coefficient on the indicator for firms that import inputs becomes statistically significant suggesting a negative correlation between importing inputs and CSR.

As discussed in Section 3, there are identification challenges in inferring a causal relationship from these estimates. We therefore use a difference GMM estimator whereby the model is estimated in first differences and the import and export variable are instrumented by their lags. Given that these variables enter the model in lags, the second lag and earlier are suitable instruments. To avoid the problem of weak instruments, we restrict the instrument set to two lags. The results are presented in column (4). Hansen's test for the validity of the instruments is satisfied. ${ }^{22}$ We find the magnitude of the effect of exporting on CSR increases substantially suggesting that OLS estimates are downward biased. The magnitude of the coefficient suggests that firms that export increase their CSR score by 2.46. Given that the average score is around five, this is a meaningful effect, implying $15 \%$ additional CSR activities after starting to export. Our results suggest that also the coefficient on imports is downward biased in OLS and it shifts from having a small negative effect using OLS (fixed

\footnotetext{
${ }^{22}$ Strictly exogenous regressors include all control variables (labour, capital, value added, profit-assets ratio and year dummies) in column (4), as well as $\mathrm{HHI}$ and sector dummies in columns (6)-(8)). We include two lags of all endogenous variables, apart from the once-lagged 4-digit sector share of importing firms as instruments. The underlying assumption for this approach is that conditional on the regressors, these variables are asymptotically uncorrelated with the error term. This is tested using the Hansen test for the validity of instrumental variables. All results are based on two-step estimations.
} 
Table 5

Impact of trade on the CSR engagement of private firms: extensive margin.

\begin{tabular}{|c|c|c|c|c|c|c|}
\hline \multicolumn{7}{|l|}{ Panel A: Aggregate CSR index } \\
\hline Dependent variable: & (1) & $(2)$ & (3) & $(4)$ & (5) & (6) \\
\hline Agg CSR index & OLS & OLS & $\mathrm{FE}$ & DIFF GMM & DIFF GMM & DIFF GMM \\
\hline L.output_export & $\begin{array}{l}0.192^{* *} \\
(0.083)\end{array}$ & $\begin{array}{l}0.261^{* * *} \\
(0.090)\end{array}$ & $\begin{array}{l}0.175^{* *} \\
(0.076)\end{array}$ & $\begin{array}{l}2.464^{* * *} \\
(0.918)\end{array}$ & $\begin{array}{l}2.332^{* * *} \\
(0.849)\end{array}$ & $\begin{array}{l}1.715^{* *} \\
(0.714)\end{array}$ \\
\hline L.input_import & $\begin{array}{l}0.017 \\
(0.084)\end{array}$ & $\begin{array}{l}-0.003 \\
(0.094)\end{array}$ & $\begin{array}{l}-0.185^{* *} \\
(0.086)\end{array}$ & $\begin{array}{l}0.915^{*} \\
(0.496)\end{array}$ & $\begin{array}{l}0.940^{*} \\
(0.518)\end{array}$ & $\begin{array}{l}0.936^{* *} \\
(0.431)\end{array}$ \\
\hline L.sector share of exporters & & & & & $\begin{array}{l}-1.148 \\
(1.180)\end{array}$ & $\begin{array}{c}-0.608 \\
(0.951)\end{array}$ \\
\hline L.sector share of importers & & & & & $\begin{array}{l}-3.729^{*} \\
(2.195)\end{array}$ & $\begin{array}{l}-2.597 \\
(1.702)\end{array}$ \\
\hline Time dummies & Yes & Yes & Yes & Yes & Yes & Yes \\
\hline Sector dummies & No & No & No & No & Yes & Yes \\
\hline Concentration & No & No & No & No & Yes & Yes \\
\hline Balanced panel & Yes & Yes & Yes & Yes & Yes & No \\
\hline Number of firms & & & 2546 & 2546 & 2546 & 4601 \\
\hline Number of obs. & 10,184 & 7638 & 7638 & 7638 & 7638 & 10,703 \\
\hline AR test stat & & & & -2.48 & -2.59 & -2.60 \\
\hline AR test $p$ value & & & & 0.01 & 0.01 & 0.01 \\
\hline Hansen test stat & & & & 0.81 & 3.76 & 3.07 \\
\hline \multicolumn{7}{|c|}{ Panel B: Disaggregated CSR index - difference GMM } \\
\hline & $(1)$ & $(2)$ & (3) & $(4)$ & $(5)$ & (6) \\
\hline Dependent variable: & Compliant & Compliant & Management & Management & Community & Community \\
\hline L.output export & $\begin{array}{l}0.836^{* *} \\
(0.373)\end{array}$ & $\begin{array}{l}0.829^{* * *} \\
(0.351)\end{array}$ & $\begin{array}{l}0.512 \\
(0.346)\end{array}$ & $\begin{array}{l}0.444 \\
(0.336)\end{array}$ & $\begin{array}{l}1.086^{*} \\
(0.607)\end{array}$ & $\begin{array}{l}1.075^{*} \\
(0.605)\end{array}$ \\
\hline L.input import & $\begin{array}{l}0.542^{* * *} \\
(0.181)\end{array}$ & $\begin{array}{l}0.561^{* * *} \\
(0.185)\end{array}$ & $\begin{array}{l}-0.062 \\
(0.200)\end{array}$ & $\begin{array}{c}-0.052 \\
(0.214)\end{array}$ & $\begin{array}{l}0.422 \\
(0.341)\end{array}$ & $\begin{array}{l}0.451 \\
(0.354)\end{array}$ \\
\hline L.sector share of exporters & & $\begin{array}{l}-0.515 \\
(0.438)\end{array}$ & & $\begin{array}{l}0.141 \\
(0.467)\end{array}$ & & $\begin{array}{c}-0.872 \\
(0.840)\end{array}$ \\
\hline L.sector share of importers & & $\begin{array}{l}-1.352^{*} \\
(0.782)\end{array}$ & & $\begin{array}{c}-0.462 \\
(0.834)\end{array}$ & & $\begin{array}{l}-1.985 \\
(1.587)\end{array}$ \\
\hline Time dummies & Yes & Yes & Yes & Yes & Yes & Yes \\
\hline Sector dummies & Yes & Yes & Yes & Yes & Yes & Yes \\
\hline Concentration & Yes & Yes & Yes & Yes & Yes & Yes \\
\hline Balanced panel & Yes & Yes & Yes & Yes & Yes & Yes \\
\hline Number of firms & 2546 & 2546 & 2546 & 2546 & 2546 & 2546 \\
\hline Number of obs. & 7638 & 7638 & 7638 & 7638 & 7638 & 7638 \\
\hline AR test stat & -0.90 & -0.79 & -4.16 & -4.19 & -2.12 & -2.17 \\
\hline AR test $p$ value & 0.37 & 0.43 & 0.00 & 0.00 & 0.03 & 0.03 \\
\hline Hansen test stat & 1.72 & 5.66 & 0.95 & 4.72 & 0.31 & 1.65 \\
\hline
\end{tabular}

Source: Authors' calculations based on data obtained from the Vietnam Technology and Competitiveness Survey (CIEM, 2012, 2013, 2014, 2015), the Vietnam Enterprise Surveys (2012-15) (GSOV, 2016b), and the UN COMTRADE database (WITS, 2016).

Notes: Robust standard errors clustered at the firm level in parentheses. Each model also includes controls for output, capital, labour and profit-assets ratio. Column (1) of Panel A presents results for the full sample of firms for comparison purposes. Columns (2) to (5) of Panel A and Panel B presents results for the sample of firms that are available for the difference GMM estimation procedure. Column (6) of Panel A presents results for the difference GMM estimation procedure for the unbalanced panel. Coefficient estimates for market concentration (Herfindahl-Hirschman Index) in columns (5) and (6) of Panel A, and all columns of Panel B, are not statistically different from zero. ${ }^{*} p<.10,{ }^{* *} p<.05$, ${ }^{* * *} p<.01$.

effects) to a positive and significant effect when using difference GMM. The magnitude of the coefficient suggests that firms that import inputs increase their CSR score by 0.92 . While lower in magnitude than the coefficient on exports, this retains economic significance, implying 5\% higher CSR engagement after starting to import.

Firms from developing countries are likely to face liabilities of origin; that is, negative perceptions about their ability to conduct their business responsibly. CSR has been found to be an effective strategy to overcome such liabilities (Marano et al., 2016). Consistent with the literature (see e.g., Bénabou and Tirole, 2010), our findings point to a greater influence of customers than input suppliers on CSR activities. They also highlight differences in how CSR is practiced in the countries of input producers compared with the export destination countries. Differences in CSR practices between countries are attributed to economic development and national business systems (Matten and Moon, 2008; Baughn et al., 2007; Chapple and Moon, 2005, 2007). Lower levels of CSR are observed in Asia than Western counterparts, excepting Japan (Chapple and Moon, 2005).

Table A.3 in the Appendix shows the changes in CSR after changing export or import status; more precisely, the proportion of firms that increase CSR when they enter and reduce CSR when they exit export markets and the proportion of firms that increase CSR when they start and reduce CSR when they stop importing. We observe both an increase in CSR activities after starting to export and a decrease in CSR activities after stopping exporting. The increase in CSR activities 
after becoming an exporter is larger (panel a) than the decrease after stopping exporting for all CSR activities, especially for management CSR (panel c). We also observe that a very small share of firms (1\%) increase CSR activities after stopping exporting (panel b) and that the same share of firms decreases CSR activities after starting to export (panel d). The increase in CSR activities after starting to export is about half a percentage point higher than the decrease (compare panels a and $\mathrm{d}$ ), while the decrease in CSR after stopping exporting is the same as the increase (panels b and c). In terms of importing, the increase in CSR activities after starting to import is about the same as the decrease (compare panels e and h), while the increase in CSR after stopping importing is about one percentage pointsmaller than the decrease (balanced sample, panels $\mathrm{f}$ and $\mathrm{g}$ ). These results combined may explain why we observe a positive effect from exporting and importing on CSR.

In columns (5) and (6), we extend the model to consider indirect trade effects. These are the effects of the presence of exporters and importers in the (4-digit) sector on the firm-level CSR score. We find no evidence to suggest that there are indirect CSR spill over effects associated with trade. ${ }^{23}$ Our results are robust to the inclusion of 2-digit sector-level dummies and the concentration control (column 5) and the use of the unbalanced panel (column 6).

The results in Table A.4 of the Appendix show that the intensive margin of trade does not have a significant impact on CSR activities of firms. This points to more tangible CSR gains when starting to export than when expanding operations in an already served country. CSR activities are, as noted, likely to change after changing the composition of stakeholders in favour of those with greater preference for CSR. We find evidence that this holds if a firm starts selling in foreign markets, but not if a firm increases the intensity of supply in a specific foreign market. Expanding trade in a specific foreign market could mean eventually facing clients with even stricter than the initial CSR requirements. Our analysis does not support this claim. Instead it appears that preferences for CSR in individual foreign markets appear to have stayed homogenous in the study period.

The CSR practices may be affected by competition between workers for employment in firms with CSR (those that provide formal contracts, have trade unions, etc.). Firms could be, in turn, competing precisely for the workers that value the CSR engagement by further increasing their CSR. To account for such a possibility, we introduce a control for revenueweighted average CSR practice of the competing firms in a specific sector. The results shown in Table A.5 in the Appendix indicate that between-sector CSR spill overs motivated by the selection of workers do not appear to be relevant for CSR adoption. Moreover, they do not appear to diminish the role of foreign trade in adopting CSR practices.

Further, we check whether the observed effect from foreign trade is due to the firms that have started or stopped trading in the observed period. The results based on the propensity score and nearest neighbour matching are shown in Table A.6 in the Appendix. ${ }^{24}$ First, the benchmark models in the first and the second row show the results for the export and import indicator variables. They confirm the positive results of foreign trade from Table 5. Second, we create indicator variables that capture whether a firm has changed its export (import) status in the observed period. The results show a positive effect from starting to export and starting to import, just like in Table 5. While stopping exporting does not appear to matter for CSR activities, stopping importing seems to have a negative effect.

In Panel B of Table 5, we estimate the difference GMM specification separately for each of the components of the CSR index. Each model is estimated using the full set of firm and sector control variables. The model is estimated using the balanced panel. ${ }^{25}$ As revealed in columns (1) and (2), the direct effect of trade on CSR is driven by compliant CSR, which refers to labour market regulations. Exporting is associated with an increase of 0.83 points on this scale, which ranges from 1 to 4 (equivalent to 21\%), while importing is associated with an increase of 0.56 (equivalent to 14\%). There does not appear to be any indirect effects of exporting on this CSR measure, while importing appears to have a negative spill over effect.

Consistent with the results presented above, we expect that domestic firms, which are exposed to increased competition from imports, will cut non-essential expenditure to be able to compete. It seems from these results that firms see compliance CSR as a non-essential investment that can be cut as a competitive response to imports. This is consistent with the rent dissipation effect of competition in a model presented by Bagnoli and Watts (2003) in which costs of providing public goods harm firm profitability more in competitive markets. Summarising evidence from several empirical studies on CSR, Crifo and Forget (2015) find, in contrast, that the relationship between competition and CSR is mostly positive. They do not exclude, however, the possibility that competition drives down prices and incomes and so reduces the willingness of entrepreneurs to invest in socially responsible actions (see also, Shleifer, 2004). This is what appears to be the case for Vietnam.

Turning to management CSR, we do not find any effect of direct or indirect trade, but we observe a positive effect of export on community CSR. As revealed in column (6), the direct effect of exporting on community CSR is 1.1 points for an indicator on a scale from 1 to 8 , implying 7\% higher community CSR engagement after starting to export.

We do not, however, find any indirect effects of exports or imports on community CSR. The positive effect of export on community CSR could indicate that foreign buyers highly value activities related to local community, perhaps due to better measurability and visibility of such actions (see, e.g., Bénabou and Tirole, 2010). In addition, earlier evidence shows

\footnotetext{
23 It is also possible that the CSR practices of exporting firms spill over to other firms located nearby. Indeed, McCaig and Pavcnik (2014) find that trade shocks are important for worker mobility in local labour markets between the formal and informal sector. We explored this possibility by including the proportion of firms that are exporters in the district in each specification but it was not well determined. This suggests that CSR spill overs do not operate through this channel.

24 A description of how the treatment effects are calculated and the balancing diagnostics are provided in the on-line Appendix.

${ }^{25}$ Using the unbalanced panel does not affect the overall story although some coefficients on the firm-level export measure are not well determined. Results are available on request.
} 
Table 6

Impact of trade on CSR engagement of private firms: destination of exports.

\begin{tabular}{|c|c|c|c|c|}
\hline & $\begin{array}{l}\text { (1) } \\
\text { Agg. CSR index }\end{array}$ & $\begin{array}{l}\text { (2) } \\
\text { Compliant }\end{array}$ & $\begin{array}{l}\text { (3) } \\
\text { Management }\end{array}$ & $\begin{array}{l}\text { (4) } \\
\text { Community }\end{array}$ \\
\hline L. export to China & $\begin{array}{l}-0.322^{* *} \\
(0.143)\end{array}$ & $\begin{array}{l}-0.009 \\
(0.052)\end{array}$ & $\begin{array}{l}-0.130^{* *} \\
(0.065)\end{array}$ & $\begin{array}{l}-0.183 \\
(0.119)\end{array}$ \\
\hline L. export to US & $\begin{array}{l}0.164 \\
(0.128)\end{array}$ & $\begin{array}{l}-0.032 \\
(0.047)\end{array}$ & $\begin{array}{l}0.005 \\
(0.065)\end{array}$ & $\begin{array}{l}0.191^{*} \\
(0.096)\end{array}$ \\
\hline L. export to Europe & $\begin{array}{l}0.150 \\
(0.123)\end{array}$ & $\begin{array}{l}-0.006 \\
(0.042)\end{array}$ & $\begin{array}{l}0.058 \\
(0.062)\end{array}$ & $\begin{array}{l}0.098 \\
(0.089)\end{array}$ \\
\hline L. export to other Asia & $\begin{array}{l}-0.015 \\
(0.121)\end{array}$ & $\begin{array}{l}-0.038 \\
(0.038)\end{array}$ & $\begin{array}{l}0.013 \\
(0.059)\end{array}$ & $\begin{array}{l}0.011 \\
(0.088)\end{array}$ \\
\hline Number of firms & 878 & 878 & 878 & 878 \\
\hline Number of obs. & 2423 & 2423 & 2423 & 2423 \\
\hline
\end{tabular}

Source: Authors' calculations based on data obtained from the Vietnam Technology and Competitiveness Survey (CIEM, 2012, 2013, 2014, 2015), the Vietnam Enterprise Surveys (2012-15) (GSOV, 2016b), and the UN COMTRADE database (WITS, 2016).

Notes: Robust standard errors clustered at the firm level in parentheses. Each model conditions on a firm exporting output and includes controls for whether the firm also imports inputs, the level of output, capital, labour, profit-assets ratio, sector-level concentration, firm fixed effects, sector fixed effects, and time dummies. ${ }^{*} p<.10$, $^{* *} p<.05$, ${ }^{* * *}$ $p<.01$.

that firms enjoy the largest productivity effect from community-related CSR activities, such as participation in local poverty alleviation programmes, community-based education and/or health programmes (Newman et al., 2016b).

The final part of our analysis examines the extent to which the destination of exports matters for the transmission of improved CSR practices. In our survey, we ask firms to identify the three most important markets they export to. As discussed, the mechanism we propose as underlying the effect of trade on CSR is that exporting changes the stakeholders of the firm. If the preferences of stakeholders are heterogeneous across countries, we also expect the CSR effect to vary.

In examining the correlation between the destination of exports and CSR, we condition on exporting and control for whether the firm imports. We estimate a fixed-effects model, which relates the CSR indices to dummy indicators for the country/region the firm exports to. We consider four main export destinations: China, US, EU, and other Asian economies.

Table A.7 of the Appendix presents summary statistics of the proportion of exporting firms that export their output to these economies each year. The most important destination is other Asian countries (excluding China), followed by Europe (excluding Eastern Europe), the US, and China. The proportion of firms exporting to China, the US, and Europe declined over the sample period. The lower part of the table shows that firms are less likely to export to the US and especially to Europe if they export to China.

We estimate each model, including the full set of firm and sector control variables. ${ }^{26}$ The results are presented in Table 6. We find very little heterogeneity across export destination markets in the impact of exporting on CSR and our coefficients are not well determined. Two results that are marginally significant emerge.

First, we find that firms that export to China engage in significantly less CSR than firms exporting to other markets. This holds for the aggregate index and is driven by the management CSR component. This index measures the commitment of management and includes four different indicators showing whether: (i) the firm has a committee that oversees CSR practices; (ii) the firm has a written CSR policy; (iii) the firm has received CSR-type certificates; and (iv) the firm is a member of any groups that promote CSR standards. Our results show that firms exporting to China score 0.13 points (3\%) lower on this index than firms exporting to other destinations. It suggests that stakeholders in China were not as concerned about the CSR practices of firms exporting goods into their market during the period under study. This is consistent with earlier findings of unique characteristics of CSR as a management practice in China (Moon and Shen, 2010) and recent evidence of declining labour standards in Africa after increasing exports to China (Adolph et al., 2017). Firms that only export to China do not have levels of CSR that are different when compared to firms that only sell domestically, as shown in Table A.8 (Panel A) in the Appendix.

Second, we find that firms that export to the US do more community CSR than other exporters. Again, this is suggestive of the possibility that the export market may matter for the transmission of CSR engagement through this mechanism. Export to other destinations, apart from China, results in more community CSR for firms that export to the Europe, as shown in Table A.8 (Panel B) in the Appendix. This finding supports the existence of a sorting equilibrium along stakeholder preferences were firms supply varying levels of the public good to different demand segments (Kitzmuller, 2012).

\footnotetext{
${ }^{26}$ We perform a similar analysis for importing firms, conditioning on whether the firm imports, and controlling for whether the firm exports. We do not find any evidence that the source country of imported inputs matters for the transmission of CSR through this channel. Results are available on request.
} 


\section{Conclusion}

This paper examined the direct and indirect effects of engagement with global markets on the socially responsible behaviour of domestic firms in Vietnam. Arguably, trade will impact on the CSR activities of firms through direct and indirect channels. When a firm enters export markets or begins to import inputs, its stakeholder composition changes, making it likely that trade will impact on CSR through this mechanism. Indirect effects from trade are also possible. Non-export firms in export-intensive sectors may increase their engagement in CSR activities in preparation for entry into export markets in the future. Similarly, non-import firms may reduce CSR activities to limit non-essential expenditures in the face of increased competition.

Using panel data on more than 4500 Vietnamese manufacturing firms for the period 2010-2013 (2546 in the balanced panel), we explored the effect of trade on CSR. We found a strong positive effect of exporting outputs and importing inputs on the CSR activities of domestic firms. This is driven by compliant CSR in the form of adherence to labour standards and regulations, as well as local community activities beyond the immediate financial interest of the firms. We find no evidence of spill overs to non-export and non-import firms.

In relation to exporting we found that the destination country of exports matters. Conditional on exporting, exporters to China engage in significantly less CSR than exporters to other countries, while exporters to the US appear to engage in more community CSR. This is suggestive of differences in the preferences of stakeholders in these markets.

Overall, our paper offers evidence that CSR is strongly related to trade and thus may involve a so far overlooked effect associated with international trade. This externality may provide a further justification for policies that encourage increased integration of domestic firms with global markets. Firms that import inputs or export output are in general more likely to pursue CSR activities. This means that policies that facilitate engagement with global markets will not only benefit the firms involved in terms of productivity and profits, they will also have knock-on effects to the benefit of society more broadly.

\section{Acknowledgements}

The authors are grateful for collaboration with staff at the Central Institute of Economic Management (CIEM) and the General Statistics Office (GSO) in Hanoi, Vietnam. Our thanks to participants at various conferences and seminars. We also highly appreciate expert comments and constructive critique by two referees and an associate editor. They helped sharpen our focus and contributed to a much stronger paper. This research was carried out under UNU-WIDER's project on Structural Transformation and Inclusive Growth in Viet Nam. The usual caveats apply.

\section{Appendix A}

Table A1

Summary statistics for all Corporate Social Responsibility (CSR) indicators.

\begin{tabular}{|c|c|c|c|c|c|c|c|c|}
\hline \multirow[b]{2}{*}{ CSR indicator } & \multicolumn{4}{|c|}{ Full sample } & \multicolumn{4}{|c|}{ Balanced sample } \\
\hline & $2010(\%)$ & $2011(\%)$ & $2012(\%)$ & $2013(\%)$ & $2010(\%)$ & $2011(\%)$ & $2012(\%)$ & $2013(\%)$ \\
\hline \multicolumn{9}{|l|}{ Compliance } \\
\hline $\begin{array}{l}\text { 1. All permanent employees have a } \\
\text { written labour contract }\end{array}$ & $100^{\mathrm{a}}$ & 93.7 & 95.8 & 94.3 & 100 & 92.9 & 38.6 & 94.3 \\
\hline $\begin{array}{l}\text { 2. Enterprise has a local/plant-level } \\
\text { trade union }\end{array}$ & 48.4 & 51.5 & 51.4 & 56.0 & 28.9 & 32.5 & 70 & 36.9 \\
\hline $\begin{array}{l}\text { 3. Enterprise pays contribution to } \\
\text { social insurance for employees }\end{array}$ & 71.3 & 74.1 & 73.9 & 79.4 & 55.8 & 58.9 & 1.7 & 64.9 \\
\hline $\begin{array}{l}\text { 4. Enterprise pays contribution to } \\
\text { health insurance for employees }\end{array}$ & 72.1 & 74.4 & 74.0 & 79.3 & 57.0 & 59.4 & 6.1 & 65.1 \\
\hline \multicolumn{9}{|l|}{ Management } \\
\hline $\begin{array}{l}\text { 1. Has committee/board overseeing CSR } \\
\text { practices }\end{array}$ & 35.7 & 36.4 & 47.8 & 45.3 & 30.7 & 29.7 & 94.2 & 38.5 \\
\hline 2. Has written down CSR policy & 72.1 & 72.1 & 74.8 & 76.0 & 68.9 & 67.7 & 30.2 & 69.5 \\
\hline $\begin{array}{l}\text { 3. Member of groups or has } \\
\text { agreements that promote CSR } \\
\text { standards }\end{array}$ & 2.6 & 2.4 & 3.4 & 2.1 & 2.1 & 1.3 & 57.5 & 1.0 \\
\hline $\begin{array}{l}\text { 4. Has been awarded CSR type } \\
\text { certifications or awards }\end{array}$ & 10.5 & 10.4 & 9.8 & 10.6 & 5.8 & 5.9 & 57.6 & 6.4 \\
\hline
\end{tabular}




\begin{tabular}{|c|c|c|c|c|c|c|c|c|}
\hline \multirow[b]{2}{*}{ CSR indicator } & \multicolumn{4}{|c|}{ Full sample } & \multicolumn{4}{|c|}{ Balanced sample } \\
\hline & $2010(\%)$ & $2011(\%)$ & $2012(\%)$ & $2013(\%)$ & $2010(\%)$ & $2011(\%)$ & $2012(\%)$ & $2013(\%)$ \\
\hline \multicolumn{9}{|l|}{ Community } \\
\hline 1. Environmental protection & 25.8 & 27.1 & 24.7 & 23.8 & 27.5 & 29.3 & 23.9 & 24.5 \\
\hline 2. Education & 7.7 & 9.0 & 8.6 & 8.6 & 6.7 & 10.2 & 8.2 & 8.3 \\
\hline 3. Infrastructure development & 8.0 & 8.1 & 7.3 & 7.4 & 7.0 & 8.5 & 6.8 & 8.1 \\
\hline 4. Healthcare services & 4.7 & 5.1 & 5.0 & 4.5 & 4.0 & 5.1 & 4.2 & 4.2 \\
\hline 5. Youth development & 3.1 & 3.5 & 3.4 & 3.4 & 4.3 & 4.3 & 3.3 & 3.8 \\
\hline 6. Poverty alleviation & 19.9 & 22.0 & 19.8 & 18.8 & 20.9 & 24.4 & 18.6 & 19.4 \\
\hline 7. Local heritage & 3.0 & 3.5 & 3.3 & 3.4 & 3.8 & 4.1 & 3.5 & 4.5 \\
\hline 8. Sporting events & 5.1 & 5.3 & 5.3 & 5.6 & 4.6 & 5.7 & 5.1 & 5.5 \\
\hline Number of observations & 6301 & 6463 & 5999 & 6073 & 2546 & 2546 & 2546 & 2546 \\
\hline
\end{tabular}

Source: Authors' calculations based on data obtained from the Vietnam Technology and Competitiveness Survey (CIEM, 2012, 2013, 2014, 2015).

Note: ${ }^{\text {a }}$ The question about labour contracts was asked differently in 2010.

Table A2

CSR activities among exporters and importers.

\begin{tabular}{|c|c|c|c|c|c|c|c|c|c|c|c|c|}
\hline & \multicolumn{4}{|c|}{ All firms } & \multicolumn{4}{|c|}{ Private domestic firms } & \multicolumn{4}{|c|}{ Private domestic firms (balanced) } \\
\hline & 2010 & 2011 & 2012 & 2013 & 2010 & 2011 & 2012 & 2013 & 2010 & 2011 & 2012 & 2013 \\
\hline \multicolumn{13}{|l|}{ (a) Exporters } \\
\hline CSR compliant & 3.53 & 3.57 & 3.63 & 3.70 & 3.25 & 3.34 & 3.41 & 3.50 & 3.36 & 3.44 & 3.49 & 3.59 \\
\hline CSR management & 1.39 & 1.42 & 1.59 & 1.54 & 1.32 & 1.35 & 1.52 & 1.47 & 1.34 & 1.4 & 1.56 & 1.51 \\
\hline CSR community & 0.75 & 0.75 & 0.69 & 0.67 & 0.96 & 0.99 & 0.95 & 0.92 & 1.01 & 1.13 & 1.03 & 1.00 \\
\hline CSR index & 5.67 & 5.75 & 5.91 & 5.92 & 5.53 & 5.68 & 5.88 & 5.90 & 5.71 & 5.97 & 6.08 & 6.1 \\
\hline $\begin{array}{l}\text { Observations } \\
\text { (b) Importers }\end{array}$ & 2074 & 2330 & 2250 & 2245 & 1026 & 1082 & 980 & 985 & 603 & 632 & 645 & 645 \\
\hline CSR compliant & 3.68 & 3.67 & 3.71 & 3.74 & 3.53 & 3.52 & 3.56 & 3.52 & 3.61 & 3.6 & 3.61 & 3.69 \\
\hline CSR management & 1.45 & 1.47 & 1.63 & 1.59 & 1.43 & 1.4 & 1.56 & 1.54 & 1.43 & 1.43 & 1.62 & 1.62 \\
\hline CSR community & 0.67 & 0.68 & 0.63 & 0.61 & 0.90 & 0.90 & 0.87 & 0.83 & 0.93 & 0.95 & 0.91 & 0.98 \\
\hline CSR Index & 5.80 & 5.81 & 5.98 & 5.94 & 5.86 & 5.82 & 5.98 & 5.89 & 5.96 & 5.98 & 6.13 & 6.29 \\
\hline $\begin{array}{l}\text { observations } \\
\text { (c) No foreign trade }\end{array}$ & 2142 & 2157 & 1720 & 1801 & 874 & 854 & 595 & 675 & 548 & 525 & 408 & 403 \\
\hline CSR compliant & 2.41 & 2.42 & 2.42 & 2.62 & 2.33 & 2.36 & 2.35 & 2.55 & 2.46 & 2.48 & 2.43 & 2.62 \\
\hline CSR management & 1.07 & 1.05 & 1.19 & 1.18 & 1.04 & 1.03 & 1.16 & 1.16 & 1.09 & 1.08 & 1.19 & 1.19 \\
\hline CSR community & 0.81 & 0.90 & 0.83 & 0.81 & 0.81 & 0.89 & 0.82 & 0.81 & 0.85 & 0.92 & 0.87 & 0.87 \\
\hline CSR index & 4.29 & 4.38 & 4.44 & 4.62 & 4.18 & 4.28 & 4.34 & 4.53 & 4.41 & 4.48 & 4.48 & 4.68 \\
\hline Observations & 3434 & 3527 & 3334 & 3333 & 3242 & 3337 & 3142 & 3138 & 1675 & 1683 & 1738 & 1732 \\
\hline
\end{tabular}

Source: Authors' calculations based on the Vietnam Technology and Competitiveness Survey (CIEM, 2012, 2013, 2014, 2015).

Table A.3

Changes in CSR after changing the export or import status.

\begin{tabular}{|c|c|c|c|c|c|c|c|c|}
\hline & $\begin{array}{l}\text { Full sample } \\
2010-11\end{array}$ & $2011-12$ & $2012-13$ & Average & $\begin{array}{l}\text { Balanced } \\
\text { 2010-11 }\end{array}$ & $2011-12$ & $2012-13$ & Average \\
\hline Non-exporting to exporting & 6.73 & 3.42 & 2.59 & 4.30 & 5.89 & 3.22 & 2.47 & 3.86 \\
\hline Exporting to non-exporting & 4.02 & 2.73 & 2.45 & 3.09 & 4.75 & 2.71 & 2.47 & 3.31 \\
\hline \multicolumn{9}{|c|}{ (a) Increase in CSR after changing from non-exporting to exporting (\%) } \\
\hline CSR compliant & 1.27 & 0.50 & 0.56 & 0.79 & 1.26 & 0.47 & 0.43 & 0.72 \\
\hline CSR management & 2.20 & 1.22 & 0.54 & 1.34 & 1.81 & 1.14 & 0.67 & 1.20 \\
\hline CSR community & 1.58 & 0.65 & 0.48 & 0.92 & 1.65 & 0.59 & 0.59 & 0.94 \\
\hline CSR index & 2.92 & 1.42 & 0.91 & 1.78 & 2.51 & 1.30 & 1.02 & 1.61 \\
\hline \multicolumn{9}{|c|}{ (b) Increase in CSR after changing from exporting to non-exporting (\%) } \\
\hline CSR Compliant & 0.96 & 0.27 & 0.10 & 0.45 & 0.86 & 0.27 & 0.08 & 0.41 \\
\hline CSR Management & 1.47 & 0.30 & 0.56 & 0.79 & 1.22 & 0.43 & 0.43 & 0.69 \\
\hline CSR Community & 0.90 & 0.73 & 0.54 & 0.73 & 0.86 & 0.79 & 0.51 & 0.72 \\
\hline CSR Index & 1.69 & 0.82 & 0.79 & 1.11 & 1.49 & 0.94 & 0.71 & 1.05 \\
\hline \multicolumn{9}{|c|}{ (c) Decrease in CSR after changing from exporting to non-exporting (\%) } \\
\hline CSR compliant & 0.62 & 0.57 & 0.12 & 0.44 & 0.55 & 0.55 & 0.20 & 0.43 \\
\hline CSR management & 1.05 & 0.47 & 0.64 & 0.73 & 1.18 & 0.39 & 0.59 & 0.72 \\
\hline CSR community & 0.71 & 0.65 & 0.54 & 0.64 & 1.06 & 0.59 & 0.43 & 0.69 \\
\hline CSR index & 1.33 & 1.00 & 0.91 & 1.08 & 1.49 & 1.10 & 0.75 & 1.11 \\
\hline
\end{tabular}


Table A.3 (continued)

\begin{tabular}{|c|c|c|c|c|c|c|c|c|}
\hline & $\begin{array}{l}\text { Full sample } \\
2010-11\end{array}$ & $2011-12$ & $2012-13$ & Average & $\begin{array}{l}\text { Balanced } \\
\text { 2010-11 }\end{array}$ & $2011-12$ & $2012-13$ & Average \\
\hline \multicolumn{9}{|c|}{ (d) Decrease in CSR after changing from non-exporting to exporting (\%) } \\
\hline CSR compliant & 0.71 & 0.32 & 0.36 & 0.47 & 0.82 & 0.35 & 0.43 & 0.54 \\
\hline CSR management & 1.10 & 0.68 & 0.33 & 0.71 & 1.10 & 0.51 & 0.35 & 0.65 \\
\hline CSR community & 0.91 & 0.53 & 0.30 & 0.59 & 0.90 & 0.59 & 0.47 & 0.65 \\
\hline CSR index & 1.49 & 0.93 & 0.61 & 1.02 & 1.41 & 1.02 & 0.82 & 1.09 \\
\hline Not importing to importing & 3.57 & 2.73 & 3.29 & 3.21 & 3.57 & 2.87 & 2.87 & 3.10 \\
\hline Importing to not importing & 4.13 & 8.78 & 3.29 & 5.36 & 4.48 & 7.46 & 3.06 & 5.00 \\
\hline \multicolumn{9}{|c|}{ (e) Increase in CSR after changing from not importing to importing (\%) } \\
\hline CSR compliant & 0.77 & 0.43 & 0.40 & 0.54 & 0.79 & 0.43 & 0.35 & 0.52 \\
\hline CSR management & 1.28 & 0.85 & 0.54 & 0.90 & 1.22 & 0.75 & 0.63 & 0.86 \\
\hline CSR community & 0.76 & 0.57 & 0.72 & 0.69 & 0.75 & 0.55 & 0.82 & 0.71 \\
\hline CSR index & 1.58 & 1.08 & 1.02 & 1.24 & 1.53 & 1.02 & 1.14 & 1.23 \\
\hline \multicolumn{9}{|c|}{ (f) Increase in CSR after changing from importing to not importing (\%) } \\
\hline CSR compliant & 0.43 & 0.35 & 0.18 & 0.32 & 0.47 & 0.27 & 0.08 & 0.27 \\
\hline CSR management & 0.82 & 0.37 & 0.63 & 0.61 & 0.82 & 0.43 & 0.43 & 0.56 \\
\hline CSR community & 0.71 & 0.6 & 0.63 & 0.65 & 0.75 & 0.63 & 0.63 & 0.67 \\
\hline CSR index & 0.96 & 0.7 & 1.00 & 0.89 & 0.98 & 0.67 & 0.79 & 0.81 \\
\hline \multicolumn{9}{|c|}{ (g) Decrease in CSR after changing from importing to not importing (\%) } \\
\hline CSR compliant & 0.96 & 0.95 & 0.10 & 0.67 & 1.06 & 0.9 & 0.16 & 0.71 \\
\hline CSR management & 1.41 & 1.30 & 0.69 & 1.14 & 1.81 & 1.02 & 0.71 & 1.18 \\
\hline CSR community & 0.91 & 1.45 & 0.54 & 0.97 & 1.18 & 1.34 & 0.63 & 1.05 \\
\hline CSR index & 1.75 & 2.33 & 0.94 & 1.67 & 2.16 & 2.04 & 0.98 & 1.73 \\
\hline \multicolumn{9}{|c|}{ (h) Decrease in CSR after changing from not importing to importing (\%) } \\
\hline CSR compliant & 0.57 & 0.88 & 0.48 & 0.64 & 0.55 & 0.82 & 0.43 & 0.60 \\
\hline CSR management & 0.96 & 1.58 & 0.48 & 1.00 & 0.90 & 1.30 & 0.31 & 0.84 \\
\hline CSR community & 0.9 & 1.15 & 0.72 & 0.92 & 0.82 & 1.06 & 0.59 & 0.82 \\
\hline CSR index & 1.21 & 2.25 & 1.07 & 1.50 & 1.14 & 1.85 & 0.82 & 1.27 \\
\hline Observations & 6463 & 5999 & 6073 & 18,535 & 2546 & 2546 & 2546 & 7638 \\
\hline
\end{tabular}

Source: Authors' calculations based on the Vietnam Technology and Competitiveness Survey (CIEM, 2012, 2013, 2014, 2015), the Vietnam Enterprise Surveys (2012-15) (GSOV, 2016b), and the UN COMTRADE database (WITS, 2016).

Table A4

Impact of the intensive margin of trade on the CSR engagement of private firms.

\begin{tabular}{|c|c|c|c|c|c|c|c|c|}
\hline Dependent var: Agg CSR index & $\begin{array}{l}(1) \\
\text { OLS }\end{array}$ & $\begin{array}{l}(2) \\
\text { OLS }\end{array}$ & $\begin{array}{l}(3) \\
\mathrm{FE}\end{array}$ & $\begin{array}{l}\text { (4) } \\
\text { DIFF GMM }\end{array}$ & $\begin{array}{l}(5) \\
\text { FE }\end{array}$ & $\begin{array}{l}(6) \\
\text { DIFF GMM }\end{array}$ & $\begin{array}{l}\text { (7) } \\
\text { DIFF GMM }\end{array}$ & $\begin{array}{l}(8) \\
\text { DIFF GMM }\end{array}$ \\
\hline L.output export proportion & $\begin{array}{l}-0.001 \\
(0.001)\end{array}$ & $\begin{array}{l}-0.000 \\
(0.001)\end{array}$ & $\begin{array}{l}0.000 \\
(0.001)\end{array}$ & $\begin{array}{l}0.041 \\
(0.033)\end{array}$ & $\begin{array}{l}0.000 \\
(0.001)\end{array}$ & $\begin{array}{l}0.053 \\
(0.038)\end{array}$ & $\begin{array}{l}0.051 \\
(0.035)\end{array}$ & $\begin{array}{l}0.038 \\
(0.029)\end{array}$ \\
\hline L.input import proportion & $\begin{array}{l}0.002 \\
(0.002)\end{array}$ & $\begin{array}{l}0.002 \\
(0.002)\end{array}$ & $\begin{array}{l}-0.001 \\
(0.001)\end{array}$ & $\begin{array}{l}0.003 \\
(0.005)\end{array}$ & $\begin{array}{l}-0.001 \\
(0.001)\end{array}$ & $\begin{array}{l}0.005 \\
(0.005)\end{array}$ & $\begin{array}{l}0.005 \\
(0.005)\end{array}$ & $\begin{array}{l}0.006 \\
(0.004)\end{array}$ \\
\hline L.export share in sector sales & & & & & $\begin{array}{l}0.693 \\
(0.510)\end{array}$ & $\begin{array}{l}0.903 \\
(0.743)\end{array}$ & $\begin{array}{l}1.032 \\
(0.817)\end{array}$ & $\begin{array}{l}0.978 \\
(0.814)\end{array}$ \\
\hline L.import share in sector sales & & & & & $\begin{array}{l}-0.608^{* *} \\
(0.284)\end{array}$ & $\begin{array}{l}-0.746 \\
(0.702)\end{array}$ & $\begin{array}{l}-0.802 \\
(0.744)\end{array}$ & $\begin{array}{l}-0.823 \\
(0.741)\end{array}$ \\
\hline Time dummies & Yes & Yes & Yes & Yes & Yes & Yes & Yes & Yes \\
\hline Sector dummies & No & No & No & No & No & No & Yes & Yes \\
\hline Concentration & No & No & No & No & No & No & Yes & Yes \\
\hline Balanced panel & Yes & Yes & Yes & Yes & Yes & Yes & Yes & No \\
\hline Number of firms & & & 2546 & 2546 & 2546 & 2546 & 2546 & 4601 \\
\hline Number of obs. & 10,184 & 7638 & 7638 & 7638 & 7638 & 7638 & 7638 & 10,703 \\
\hline AR test stat & & & & -2.50 & & 0.48 & 0.51 & -0.58 \\
\hline AR test $p$ value & & & & 0.01 & & 0.63 & 0.61 & 0.56 \\
\hline Hansen test stat & & & & 4.26 & & 5.37 & 5.39 & 5.22 \\
\hline
\end{tabular}

Source: Authors' calculations based on data obtained from the Vietnam Technology and Competitiveness Survey (CIEM, 2012, 2013, 2014, 2015), the Vietnam Enterprise Surveys (2012-15) (GSOV, 2016b), and the UN COMTRADE database (WITS, 2016).

Notes: Robust standard errors clustered at the firm level in parentheses. Each model also includes controls for output, capital, labour and profit-assets ratio. Column (1) presents results for the full sample of firms for comparison purposes. All other columns present results for the sample of firms that are available for the difference GMM estimation procedure. Coefficient estimates for market concentration (Herfindahl-Hirschman Index) in columns (7) and (8) are not statistically different from zero. ${ }^{*} p<.10,{ }^{* *} p<.05,{ }^{* * *} p<.01$. 
Table A5

Trade and CSR: accounting for sector spill overs between firms competing for similar workers.

\begin{tabular}{|c|c|c|c|c|c|c|c|c|}
\hline Dependent var: Agg CSR index & $\begin{array}{l}\text { (1) } \\
\text { OLS }\end{array}$ & $\begin{array}{l}(2) \\
\text { OLS }\end{array}$ & $\begin{array}{l}(3) \\
\mathrm{FE}\end{array}$ & $\begin{array}{l}\text { (4) } \\
\text { DIFF GMM }\end{array}$ & $\begin{array}{l}(5) \\
\mathrm{FE}\end{array}$ & $\begin{array}{l}(6) \\
\text { DIFF GMM }\end{array}$ & $\begin{array}{l}(7) \\
\text { DIFF GMM }\end{array}$ & $\begin{array}{l}(8) \\
\text { DIFF GMM }\end{array}$ \\
\hline L.output export & $\begin{array}{l}0.268^{* * *} \\
(0.090)\end{array}$ & $\begin{array}{l}0.286^{* * * *} \\
(0.100)\end{array}$ & $\begin{array}{l}0.063 \\
(0.120)\end{array}$ & $\begin{array}{l}1.933^{* *} \\
(0.972)\end{array}$ & $\begin{array}{l}0.066 \\
(0.120)\end{array}$ & $\begin{array}{l}3.121^{* * *} \\
(1.130)\end{array}$ & $\begin{array}{l}3.042^{* * *} \\
(1.128)\end{array}$ & $\begin{array}{l}1.925^{* *} \\
(0.833)\end{array}$ \\
\hline L.input import & $\begin{array}{l}-0.021 \\
(0.093)\end{array}$ & $\begin{array}{l}0.020 \\
(0.100)\end{array}$ & $\begin{array}{l}-0.126 \\
(0.108)\end{array}$ & $\begin{array}{l}0.871^{*} \\
(0.479)\end{array}$ & $\begin{array}{l}-0.130 \\
(0.108)\end{array}$ & $\begin{array}{l}1.198^{* *} \\
(0.595)\end{array}$ & $\begin{array}{l}1.213^{* *} \\
(0.599)\end{array}$ & $\begin{array}{l}0.993 * * \\
(0.451)\end{array}$ \\
\hline L.CSR competition & $\begin{array}{l}-0.088 \\
(0.054)\end{array}$ & $\begin{array}{l}-0.108^{*} \\
(0.058)\end{array}$ & $\begin{array}{l}0.146^{* *} \\
(0.073)\end{array}$ & $\begin{array}{l}0.681 \\
(0.442)\end{array}$ & $\begin{array}{l}0.148 * * \\
(0.075)\end{array}$ & $\begin{array}{l}0.022 \\
(0.541)\end{array}$ & $\begin{array}{l}0.361 \\
(0.324)\end{array}$ & $\begin{array}{l}0.020 \\
(0.323)\end{array}$ \\
\hline L.sector share of exporters & & & & & $\begin{array}{l}0.122 \\
(2.017)\end{array}$ & $\begin{array}{l}-0.831 \\
(1.596)\end{array}$ & $\begin{array}{l}-0.754 \\
(1.576)\end{array}$ & $\begin{array}{c}-0.084 \\
(1.365)\end{array}$ \\
\hline L.sector share of importers & & & & & $\begin{array}{l}0.001 \\
(1.639)\end{array}$ & $\begin{array}{l}-4.673^{*} \\
(2.538)\end{array}$ & $\begin{array}{l}-4.846^{*} \\
(2.584)\end{array}$ & $\begin{array}{l}-2.598 \\
(1.995)\end{array}$ \\
\hline Time dummies & Yes & Yes & Yes & Yes & Yes & Yes & Yes & Yes \\
\hline Sector dummies & No & No & No & No & No & No & Yes & Yes \\
\hline Concentration & No & No & No & No & No & No & Yes & Yes \\
\hline Balanced panel & Yes & Yes & Yes & Yes & Yes & Yes & Yes & No \\
\hline Number of firms & 2546 & 2546 & 2546 & 2546 & 2546 & 2546 & 2546 & 4601 \\
\hline Number of obs. & 7636 & 5090 & 5090 & 5090 & 5090 & 5090 & 5090 & 7467 \\
\hline
\end{tabular}

Source: Authors' calculations based on the Vietnam Technology and Competitiveness Survey (CIEM, 2012, 2013, 2014, 2015), the Vietnam Enterprise Surveys (2012-15) (GSOV, 2016b), and the UN COMTRADE database (WITS, 2016).

Note: Variable CSR competition shows revenue-weighted average CSR practice of the competing firms in a specific sector.

Table A6

Results for the matching estimators (propensity score matching (PSM) and nearest neighbour (NN) matching).

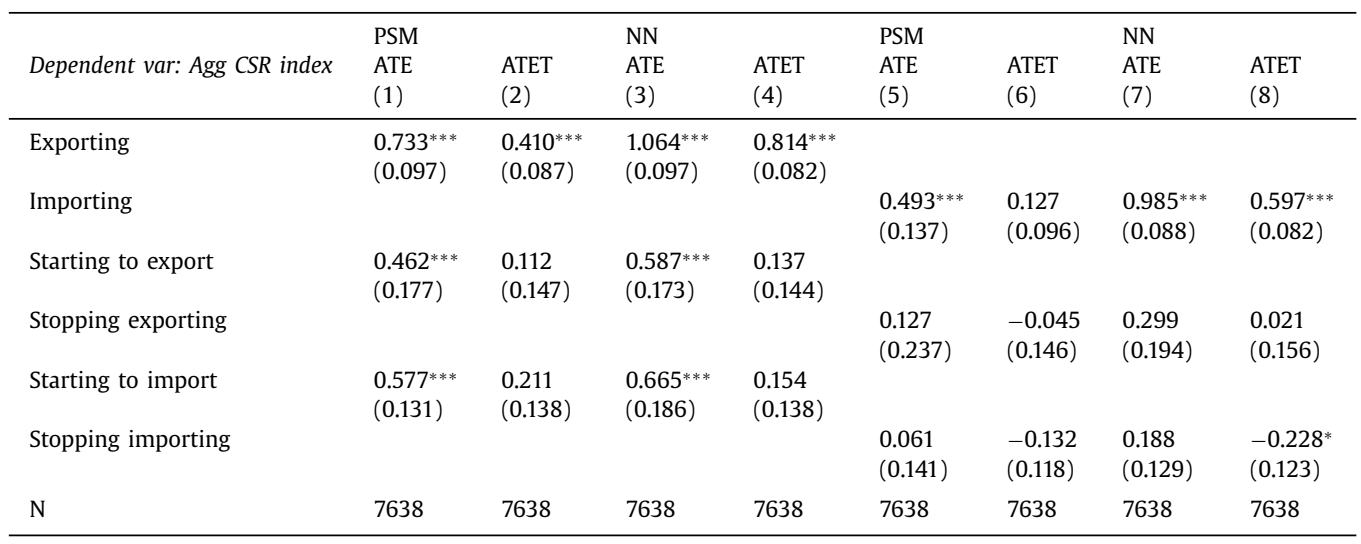

Source: Authors' calculations based on the Vietnam Technology and Competitiveness Survey (CIEM, 2012, 2013, 2014, 2015), the Vietnam Enterprise Surveys (2012-15) (GSOV, 2016b), and the UN COMTRADE database (WITS, 2016).

Notes: Matching for five nearest neighbours. Robust standard errors clustered at the firm level in parentheses. Each model controls for the level of output, capital, labour, profit-assets ratio, sector-level concentration, foreign trade spill overs, firm fixed effects, and time dummies. Industry dummies are not included for starting to (stopping) export(ing) or for starting to (stopping) import(ing) due to perfect prediction in some industries. ${ }^{*} \mathrm{p}<.10,{ }^{* *} \mathrm{p}<.05$, ${ }^{* * *} \mathrm{p}<.01$.

Table A7

Export destination.

\begin{tabular}{lcccc}
\hline $\begin{array}{l}\text { Variable name } \\
\text { Per cent of exporting firms }\end{array}$ & 2010 & 2011 & 2012 & 2013 \\
\hline China & & & & \\
US & 12.6 & 13.8 & 13.3 & 13.2 \\
Europe & 25.4 & 27.2 & 27.1 & 26.4 \\
Other Asia & 33.3 & 34.7 & 33.6 & 34.3 \\
Exporting to China and other countries & 42.1 & 44.8 & 44.2 & 43.7 \\
US & 13.2 & 16.1 & 15.1 & 10.6 \\
Europe & 10.5 & 14.9 & 11.6 & 17.6 \\
Other Asia & 51.3 & 51.7 & 41.9 & 40.0 \\
Number of firms & 603 & 632 & 645 & 645 \\
\hline
\end{tabular}

Source: Authors' calculations based on data obtained from the Vietnam Technology and Competitiveness Survey (CIEM, 2012, 2013, 2014, 2015). 
Table A8

The effect of exporting to China.

\begin{tabular}{|c|c|c|c|c|}
\hline Panel A: The effect of exporting & $\begin{array}{l}\text { o China compare } \\
\text { (1) } \\
\text { Agg. CSR index }\end{array}$ & $\begin{array}{l}\text { (2) non-expor } \\
\text { Compliant }\end{array}$ & $\begin{array}{l}\text { ng } \\
\text { Management }\end{array}$ & $\begin{array}{l}\text { (4) } \\
\text { Community }\end{array}$ \\
\hline L.export to China vs. no export & $\begin{array}{l}0.022 \\
(0.200)\end{array}$ & $\begin{array}{l}0.072 \\
(0.095)\end{array}$ & $\begin{array}{l}-0.059 \\
(0.104)\end{array}$ & $\begin{array}{l}0.009 \\
(0.152)\end{array}$ \\
\hline $\begin{array}{l}\text { Number of firms } \\
\text { Number of obs. }\end{array}$ & $\begin{array}{l}2305 \\
8368\end{array}$ & $\begin{array}{l}2305 \\
8368\end{array}$ & $\begin{array}{l}2305 \\
8368\end{array}$ & $\begin{array}{l}2305 \\
8368\end{array}$ \\
\hline \multicolumn{5}{|c|}{ Panel B: The effect of exporting to China and other countries on CSR engagement } \\
\hline & $\begin{array}{l}\text { (1) } \\
\text { Agg. CSR index }\end{array}$ & $\begin{array}{l}(2) \\
\text { Compliant }\end{array}$ & $\begin{array}{l}(3) \\
\text { Management }\end{array}$ & $\begin{array}{l}\text { (4) } \\
\text { Community }\end{array}$ \\
\hline L.export to US & $\begin{array}{l}0.502 \\
(0.510)\end{array}$ & $\begin{array}{l}-0.131 \\
(0.121)\end{array}$ & $\begin{array}{l}-0.016 \\
(0.180)\end{array}$ & $\begin{array}{l}0.649 \\
(0.447)\end{array}$ \\
\hline L.export to Europe & $\begin{array}{l}1.369 * * \\
(0.556)\end{array}$ & $\begin{array}{l}0.077 \\
(0.212)\end{array}$ & $\begin{array}{l}0.007 \\
(0.157)\end{array}$ & $\begin{array}{l}1.285^{* * *} \\
(0.447)\end{array}$ \\
\hline L. export to other Asia & $\begin{array}{l}0.055 \\
(0.318)\end{array}$ & $\begin{array}{l}-0.201^{* *} \\
(0.100)\end{array}$ & $\begin{array}{l}0.012 \\
(0.161)\end{array}$ & $\begin{array}{l}0.244 \\
(0.218)\end{array}$ \\
\hline Number of firms & 176 & 176 & 176 & 176 \\
\hline Number of obs. & 334 & 334 & 334 & 334 \\
\hline
\end{tabular}

Source: Authors' calculations based on the Vietnam Technology and Competitiveness Survey (CIEM, 2012, 2013, 2014, 2015), the Vietnam Enterprise Surveys (2012-15) (GSOV, 2016b), and the UN COMTRADE database (WITS, 2016).

Notes: Robust standard errors clustered at the firm level in parentheses. Each model conditions on a firm exporting output and includes controls for whether the firm also imports inputs, the level of output, capital, labour, profit-assets ratio, sector-level concentration, foreign trade spill overs, firm fixed effects, sector fixed effects, and time dummies. ${ }^{*} p<.10,{ }^{* *} p<.05,{ }^{* * *} p<.01$.

\section{Supplementary materials}

Supplementary material associated with this article can be found, in the online version, at doi:10.1016/j.euroecorev.2017. 10.013.

\section{References}

Adolph, C., Quince, V., Prakash, A., 2017. The Shanghai effect: do exports to China affect labor practices in Africa. World Dev. 89, 1-18.

Albornoz, F., Cole, M.A., Elliott, R.J.R., Ercolani, M.G., 2014. The environmental actions of firms: examining the role of spillovers, networks and absorptive capacity. J. Environ. Manag. 146, 150-163.

Aldashev, G., Limardi, M., Verdier, T., 2015. Watchdogs of the invisible hand: NGO monitoring and industry equilibrium. J. Dev. Econ. 116, 28-42.

Amiti, M., Konings, J., 2007. Trade liberalization, intermediate inputs and productivity: evidence from Indonesia. Am. Econ. Rev. 97 (5), 1611-1638.

Arellano, M., Bond, S., 1991. Some tests of specification for panel data: Monte Carlo evidence and an application to employment equations. Rev. Econ. Stud. 58 (2), 277-297.

Aw, B., Roberts, M., Winston, T., 2007. Export market participation, investments in R\&D and worker training, and the evolution of firm productivity. World Econ. 14 (1), 83-104.

Aw, B., Roberts, M., Yi Xu, D., 2011. R\&D investments, exporting, and productivity dynamics. Am. Econ. Rev. 101 (4), $1312-1344$.

Bagnoli, M., Watts, S.G., 2003. Selling to socially responsible consumers: competition and the private provision of public goods. J. Econ. Manag. Strategy 12 (3), 419-445.

Baron, D.P., 2001. Private politics, corporate social responsibility, and integrated strategy. J. Econ. Manag. Strategy 10 (1), 7-45.

Barrett, H.R., Browne, A.W., Harris, P.J.C., Cadoret, K., 2002. Organic certification and the UK market: organic imports from developing countries. Food Policy 27 (4), 301-318.

Baughn, C.C., Bodie, N.L.(Dusty), McIntosh, J.C., 2007. Corporate social and environmental responsibility in Asian countries and other geographical regions. Corporate Soc. Responsib. Environ. Manag. 14 (4), 189-205.

Bénabou, R., Tirole, J., 2010. Individual and corporate social responsibility. Economica 77 (305), 1-19.

Besley, T., Ghatak, M., 2007. Retailing public goods: the economics of corporate social responsibility. J. Publ. Econ. 91 (9), $1645-1663$.

Blalock, G., Gertler, P.J., 2008. Welfare gains from foreign direct investment through technology transfer to local suppliers. J. Int. Econ. 74 (2), 402-421.

Boston College Center for Corporate Citizenship (BCCCC), 2011. The 2010 Corporate Social Responsibility Index. Boston College Center for Corporate Citizenship and Reputation Institute, Boston, MA

Campbell, J.L., 2007. Why would corporations behave in socially responsible ways? An institutional theory of corporate social responsibility. Acad. Manag. Rev. 32 (3), 946-967.

Carroll, A.B., 1979. A three-dimensional conceptual model of corporate performance. Acad. Manag. Rev. 4 (4), $497-505$.

Carroll, A.B., 1991. The pyramid of corporate social responsibility: toward the moral management of organizational stakeholders. Bus. Horiz. 34 (4), 39-48.

Castka, P., Balzarova, M.A., 2008. ISO 26000 and supply chains-on the diffusion of the social responsibility standard. Int. J. Prod. Econ. 111 (2), 274-286.

Central Institute for Economic Management (CIEM) and University of Copenhagen, 2012. Technology and competitiveness in Vietnam: Evidence from a Survey in 2011. Ha Noi: CIEM.

Central Institute for Economic Management (CIEM) and University of Copenhagen., 2013. Technology and Competitiveness in Vietnam: Evidence from a Survey in 2012. Ha Noi: CIEM.

Central Institute for Economic Management (CIEM) and University of Copenhagen, 2014. Technology and Competitiveness in Vietnam: Evidence from a Survey in 2013. Ha Noi: CIEM.

Central Institute for Economic Management (CIEM), University of Copenhagen, 2015. Technology and Competitiveness in Vietnam: Evidence from a Survey in 2014. Ha Noi:, CIEM. 
Chapple, W., Moon, J., 2005. Corporate social responsibility (CSR) in Asia: a seven-country study of CSR web site reporting. Bus. Soc. 44 (4), 415-441.

Chapple, W., Moon, J., 2007. CSR agendas for Asia. Corporate So. Responsib. Environ. Manag. 14 (4), $183-188$.

Chatterji, A.K., Levine, D.I., Toffel, M.W., 2009. How well do social ratings actually measure corporate social responsibility. J. Econ. Manag. Strategy 18 (1), 125-169.

Corbett, C.J., Kirsch, D.A., 2001. International diffusion of ISO 14000 certification. Prod. Oper. Manag. 10 (3), $327-342$.

Crifo, P., Forget, V.D., 2015. The economics of corporate social responsibility: a firm-level perspective survey. J. Econ. Surveys 29 (1), $112-130$.

Cruz, A., Newman, C., Rand, J., Tarp, F., 2017. Learning by exporting: the case of Mozambican manufacturing. J. Afr. Econ. 26 (1), 67-92.

Delmas, M., Toffel, M.W., 2004. Stakeholders and environmental management practices: an institutional framework. Bus. Strategy Environ. 13 (4), $209-222$.

De Loecker, J., 2007. Do exports generate higher productivity? Evidence from Slovenia. J. Int. Econ. 73 (1), 69-98.

Fair Labor Association (FLA), 2012. Promoting sustainable corporate social responsibility in Vietnam. Available at: http://www.fairlabor.org/our-work/ special-projects/project/promoting-sustainable-corporate-social-responsibility-vietnam (accessed on 14 May 2016).

Fernandes, A., 2007. Trade policy, trade volumes and plant-level productivity in Columbian manufacturing industries. J. Int. Econ. 71, 52-71.

Fikru, M.G., 2014. Firm level determinants of international certification: evidence from Ethiopia. World Dev. 64, $286-297$.

General Statistics Office of Viet Nam (GSOV), 2016b. Vietnam Enterprise Surveys for years 2012-15. Ha Noi: GSO. Available at: http://www.gso.gov.vn (accessed on 18 May 2016).

Gereffi, G., Humphrey, J., Sturgeon, T.J., 2005. The governance of global value chains. Rev. Int. Political Econ. 12 (1), $78-104$.

Gjølberg, M., 2009. Measuring the immeasurable?: Constructing an index of CSR practices and CSR performance in 20 countries. Scand. J. Manag. 25 (1), $10-22$.

Gond, J.-P., Kang, N., Moon, J., 2011. The government of self-regulation: on the comparative dynamics of corporate social responsibility. Econ. Soc. 40 (4), $640-671$.

Herzfeld, T., Drescher, L.S., Grebitus, C., 2011. Cross-national adoption of private food quality standards. Food Policy 36 (3), $401-411$.

Husted, B.W., de Jesus Salazar, J., 2006. Taking Friedman seriously: maximizing profits and social performance. J. Manag. Stud. 43 (1), $75-91$.

ISO, 2012. ISO 26000 - social responsibility. Available at: http://www.iso.org/iso/iso26000 (accessed on 14 May 2016 ).

Jensen, M.C., 2002. Value maximization, stakeholder theory, and the corporate objective function. Bus. Eth. Q. 12 (2), $235-256$.

Kanter, R.M., 1999. From spare change to real change: the social sector as beta site for business innovation. Harv. Bus. Rev. 77 (3), $122-132$.

Kasahara, H., Rodrigue, J., 2008. Does the use of imported intermediates increase productivity? Plant-level evidence. J. Dev. Econ. 87, 106-118.

Kitzmuller, M., 2012. Is better information always good news? International corporate strategy and regulation. Policy Research Working Paper Series No. 6251. Washington, DC: The World Bank.

Kitzmueller, M., Shimshack, J., 2012. Economic perspectives on corporate social responsibility. J. Econ. Literature 50 (1), $51-84$.

Kolstad, I., 2016. Three questions about engagement and exclusion in responsible investment. Bus. Eth. Eur. Rev. 25 (1), $45-58$.

Lileeva, A., Trefler, D., 2010. Improved access to foreign markets raises plant-level productivity... for some plants. Q. J. Econ. 125 (3), 1051-1099.

Marano, V., Tashman, P., Kostova, T., 2016. Escaping the iron cage: liabilities of origin and CSR reporting of emerging market multinational enterprises. J. Int. Bus. Stud. 48 (3), 386-408.

Matten, D., Moon, J., 2008. "Implicit” and “explicit” CSR: a conceptual framework for a comparative understanding of corporate social responsibility. Acad. Manag. Rev. 33 (2), 404-424.

McCaig, B., and Pavcnik, N., 2014. Export markets and labor allocation in a low-income country. Working Paper Number 20455 NBER.

McWilliams, A., Siegel, D., 2001. Corporate social responsibility: a theory of the firm perspective. Acad. Manag. Rev. 26 (1), $117-127$.

Moon, J., Shen, X., 2010. CSR in China research: salience, focus and nature. J. Bus. Eth. 94 (4), 613-629.

Newman, C., Rand, J., Tarp, F., 2013. Industry switching in developing countries. World Bank Econ. Rev. 27 (2), $357-388$.

Newman, C., Rand, J., Tarp, F., 2016a. Imports, Supply Chains and Productivity. Mimeo.

Newman, C., J. Rand, F. Tarp, and Trifkovic N., 2016b. Corporate social responsibility in a competitive business environment. UNU-WIDER Working Paper 2016/7. Helsinki: UNU-WIDER.

Newman, C., Rand, J., Tarp, F., Anh, T., 2017. Exporting and productivity: learning from Vietnam.'. J. Afr. Econ. 26 (1), 67-92.

Nguyen, Q.V., 2007. Current Status of CSR in Vietnam. Asian Development Bank, Tokyo.

Orlitzky, M., Siegel, D.S., Waldman, D.A., 2011. Strategic corporate social responsibility and environmental sustainability. Bus. Soc. 50 (1), 6-27.

Perez-Batres, L.A., Miller, V.V., Pisani, M.J., 2010. CSR, sustainability and the meaning of global reporting for latin American corporations. J. Bus. Eth. 91 (2), $193-209$.

Porter, M.E., Kramer, M.R., 2002. The competitive advantage of corporate philanthropy. Harv. Bus. Rev. 80 (12), $56-68133$.

Porter, M.E., van der Linde, C., 1995. Toward a new conception of the environment-competitiveness relationship. J. Econ. Perspect. 9 (4), 97-118.

Potoski, M., Prakash, A., 2004. Regulatory convergence in nongovernmental regimes? Cross-national adoption of ISO 14001 certifications. J. Politics 66 (3), 885-905.

Puga, D., Trefler, D., 2010. Wake up and smell the ginseng: International trade and the rise of incremental innovation in low-wage countries. J. Dev. Econ. $91(1), 64-76$.

Reinhardt, F.L., Stavins, R.N., Vietor, R.H.K., 2008. Corporate social responsibility through an economic lens. Rev. Environ. Econ. Policy 2 (2), 219-239.

Schwartz, M.S., Carroll, A.B., 2003. Corporate social responsibility: a three-domain approach. Bus. Ethics Q. 13 (4), 503-530.

Shleifer, A., 2004. Does competition destroy ethical behaviour? Am. Econ. Rev. 94 (2), 414-418.

Turker, D., 2009. Measuring corporate social responsibility: a scale development study. J. Bus. Eth. 85 (4), $411-427$.

United Nations (UN), 2013. The ten principles of the UN global compact. Available at: https://www.unglobalcompact.org/what-is-gc/mission/principles (accessed on 14 May 2016).

United Nations (UN), 2014. The global compact viet nam network. Available at: http://www.un.org.vn/en/spotlight-articles-press-centre-submenu-253/ news-highlights-press-centre-submenu-254/27-the-un-in-viet-nam/global-compact/295-the-global-compact-viet-nam-network.html (accessed on 14 May 2016).

United Nations Industrial Development Organization (UNIDO), 2011. Baseline Survey Report 2010: Awareness, Understanding And Usage of Social Cooperate Responsibility (CSR) Among Vietnam‘s Small and Medium Enterprises. Vienna: United Nations Industrial Development Organization.

Van Biesebroeck, J., 2005. Exporting raises productivity in sub-Saharan African manufacturing firms. J. Int. Econ. 67, 373-391.

Vogel, D., 2005. The Market for Virtue: The Potential and Limits of Corporate Social Responsibility. The Brookings Institution, Washington, DC.

World Integrated Trade Solution (WITS), 2016. UN COMTRADE database. Available at: http://wits.worldbank.org/ (accessed on 18 May 2016).

Zhu, Q., Cordeiro, J., Sarkis, J., 2012. International and domestic pressures and responses of Chinese firms to greening. Ecol. Econ. 83, 144-153. 